\title{
TRAINING GENDER: DISCURSIVE ANALYSIS
}

\section{The discourse of 'gender-awareness' training in peace and security - a discursive analysis of the United Nations' "Gender and Peacekeeping" toolkit}

\section{By Sarah Lobrot}

A thesis submitted to the Victoria University of Wellington in partial fulfilment of the requirements for the degree of Master of International Relations (MIR)

School of History, Philosophy, Political Science and International Relations

Victoria University of Wellington 2010 


\section{ACKNOWLEDGMENTS}

I would like to acknowledge my supervisor, the MIR programme coordinator and MIR student peers for their support, guidance and insightful conversations, which have helped me in preparing my thesis, as well as adjusting to life in New Zealand whilst studying. An unforgettable and wonderful experience! 


\begin{abstract}
The aim of this thesis is to examine the discursive practices that have arisen from gender training in peace operations with the following research questions: "how is the discourse of 'gender-awareness' constructed through UN gender-training material for peacekeepers? How does this discourse contribute to further shaping representations of gender, violence and security?" To help answer my research questions, I proceed to a discourse analysis of the gender-training package created in 2001 by the United Nations Department of Peacekeeping Operations (UN DPKO) called Gender and Peacekeeping In-Mission Training.
\end{abstract}

The analytical frameworks chosen for this research paper are Michel Foucault's notion of discourse and Laura Shepherd's 'analytical strategies'. Using Foucault's understanding of discourse, this paper examines the social practices of gender in the military field (peace and security): how are these social practices embedded in knowledge (in what ways are the notions of gender approached? Do they form a universal truth?)? How does this discourse act through and upon subjects (male and female peacekeepers)?

Building on Shepherd's work, this thesis seeks to interrogate and deconstruct the concept of 'gender-awareness' in the UN training material around three dominant discursive sites (called Shepherd's 'nodal points'): [1] 'how the relations between women and men are structured' (gender), [2] 'how they are affected by violent conflict' (gender and violence), and [3] 'how the mere presence of peacekeepers further impacts on those relations' (gender, violence and security).

The literature review first addresses the construction of feminities and masculinities in war and peace. It demonstrates that women are constructed as being 'peacemakers' and that their feminity is shaped as being 'peaceful' and as 'mother of the nation' whilst masculinities are shaped through war. Secondly, it looks at the ways in which gender has been integrated (or mainstreamed) into UN policies: showing gender as a synonym for women. 
The research discovers that 'gender-awareness' as a discourse in the UN gendertraining material is composed of: [1] gender that equates 'sex' and 'women', [2] the dichotomy between women positioned as 'victims' and men as 'heroes' (expected normal behaviour) and [3] universals such as women's rights, which ignore cultural contexts in their approach to gender. The paper also further investigates the discourse of 'gender-awareness training', which I argue has been established as a 'tool' in the military field, but not as a critical concept. This tool seeks to produce understanding (knowledge, i.e. what is produced as truth) of gender, violence and security and to regulate the agents' (i.e. male peacekeepers') behaviours.

These findings are important as they add to the literature which demonstrates how gender is de-politicised while sex is politicised and how women are excluded from both the realm of peace (security) and the realm of war (violence). It reinforces the idea that discourse is repeated and that for the UN to (re-)think gender in meaningful and creative ways, it becomes necessary to deconstruct the way power structures are shared. 


\section{TABLE OF CONTENTS}

INTRODUCTION

CHAPTER 1 - ANALYTICAL FRAMEWORK AND METHODOLOGY .13

Foucault's power and knowledge

Discourse as a site of struggle

Shepherd's analytical strategies

Applied methodology

CHAPTER 2 - LITERATURE REVIEW.

Gender, violence and security

1- Construction of (peaceful) feminities: women as peacemakers

2- Formation of (hegemonic) militarised masculinities

The UN gender policies in peace - UNSCR 1325

1- Gender mainstreaming: promoting gender equality

2- Protecting women: women as 'vulnerable'

CHAPTER 3 - ANALYSIS OF 'GENDER-AWARENESS' DISCOURSE . .46

Contextualising gender training in peacekeeping

Descriptive reading (presentation of the material)

Analytical reading

1- 'How the relations between women and men are structured' (gender)

2- 'How [gender is] affected by violent conflict' (gender and violence)

3- 'How the mere presence of peacekeepers further impacts on [gendered] relations' (gender, violence and security)

Gender-awareness training as a technology

CONCLUSION .78

BIBLIOGRAPHY .81 


\section{INTRODUCTION}

The 2007 UN (United Nations) Working Paper "Gender Training for Peacekeepers: Preliminary Overview of United Nations Peace Support Operations" voiced the belief that a 'peace' that does not fulfil the needs of the community but instead contributes to the inferiorisation and reduction of women's roles within such a community is not worth having. ${ }^{1}$

This statement echoes an increased focus on the effects of gender relations in conflict. This issue was first addressed in 2000 with the Windhoek Declaration, Namibia Plan of Action and the United Nations Security Council Resolution 1325 (UNSCR 1325) on "Women, Peace and Security".

UNSCR 1325 addressed both violence against women and women's contributions in periods of conflict. ${ }^{2}$ UNSCR 1325 is therefore recognised as being the first policy to address the different ways conflicts impact men and women. Furthermore, it is recognised as being a major step towards the integration (or mainstreaming) of gender into UN policies in peace and security.

The importance of gender training for peacekeepers has been given recognition as a direct consequence of UNSCR 1325. In particular, "the protection, special needs and human rights of women and children in conflict situations" have been emphasised. ${ }^{3}$ Gender training materials have, therefore, been developed, tested and

\footnotetext{
1 Angela Mackay, "Training the Uniforms: Gender and Peacekeeping Operations", Development in Practice 13, no. 2/3 (2003). And Minna Lyytikäinen, "Gender Training for Peacekeepers: Preliminary Overview of United Nations Peace Support Operations," (UN-INSTRAW Gender, peace and Security Working paper 4, 2007).

$2 \quad$ Laura J Shepherd, Gender, Violence and Security: Discourse as Practice (London; New York: Zed Books, 2008). And: Peter Purkarthofer, "Gender and Gender Mainstreaming in International Peacebuilding" (paper presented at the ISA Conference, 22-25 March 2006). See also Ulrike Krause, "Women in Peace and Conflict? The Need of Female Representation and Participation," A Different View, no. 33 (2009). Sandra Whitworth, Men, Militarism, and Un Peacekeeping: A Gendered Analysis (Boulder, Colo.: Lynne Rienner Publishers, 2007).

3 Megan Bastick, Karin Grimm, and Rahel Kunz, Sexual Violence in Armed Conflict: Global Overview and Implications for the Security Sector (Geneva: Geneva Centre for the Democratic Control of Armed Forces, 2007). 172 and: United Nations Development Fund for Women (UNIFEM), www.womenwarpeace.org/docs/Annotated_1325.pdf.
} 
implemented in various peace-support operations. ${ }^{4}$ Indeed, the UN argues that "by distinguishing between sex (a biological term) and gender (a social and cultural construct), gender training challenges traditional ways of thinking and uncovers common assumptions about women and men".

This thesis aims to examine the discursive practices that have arisen from gender training in peace operations. To do so I propose to analyse the discourse of the gender-training package created in 2001 by the United Nations Department of Peacekeeping Operations (UN DPKO). This training material is called Gender and Peacekeeping In-Mission Training and it delivers in-mission training on the meaning and implications of gender in peace operations. ${ }^{6}$

I believe that analysing the UN DPKO gender-training material for peacekeepers is relevant because it provides a basis for analysing the construction of gender and how gender interrelates with the concepts of violence and security. Peacekeeping is the field in which the most significant progress has been made on the implementation of UNSCR 1325, therefore this analysis provides a good starting point for a discussion on gender in peace and security. ${ }^{7}$

Furthermore, whilst there is some literature on the different ways the UN has mainstreamed gender in its policies, and about the construction of feminities and masculinities in war, little research has been done on the implementations of such policies. There is very little research that proposes a critical perspective on gender implementation, that is, on gender training in peace operations.

$4 \quad$ Training Gender and Peacekeeping, from the UN DPKO, has been tested in the Democratic Republic of Congo (MONUC), East Timor (UNMISET), Ethiopia and Eritrea (UNMEE), Kosovo (UNMIK), Liberia (UNMIL) and Sierra Leone (UNAMSIL). Natalie Florea Hudson, "En-Gendering Un Peacekeeping Operations," International Journal 60 (2005).

$5 \quad$, Gender Resource Package for Peacekeeping Operations (New York: UN DPKO, 2004), United Nations Department of Peacekeeping Operations, "Gender Mainstreaming in Peacekeeping Operations - Progress Report."

6 (UN DPKO) United Nations Department of Peacekeeping Operations, Gender and Peacekeeping Operations in-Mission Training (New York: UN DPKO, 2004).

$7 \quad$, "Gender Mainstreaming in Peacekeeping Operations - Progress Report," (UN DPKO, 
Therefore, this research challenges the assumption that analysing discursive practices should stop at the level of policies, without exploring further how discourse could be (re)produced through the implementation of such policies. Furthermore, whilst the concepts of 'gender mainstreaming' and 'gender equality' have been extensively discussed in the literature, not much has been said about 'gender-awareness', which is a concept that I seek to explore.

To help me examine the discursive practices in the UN gender-training material, I have adopted my methodology from both Michel Foucault's notion of discourse and Laura Shepherd's 'analytical strategies.' ${ }^{8}$ Foucault understands discourses as social practices that are embedded in knowledge (as the formation of universal truth) and power (as acting through subjects). ${ }^{9}$

This is important for my analysis as I propose to examine the social practices of gender as a discourse in the military field (peace and security): that is, how are these social practices embedded in knowledge (in what ways are the notions of gender approached? Do they form a universal truth?)? How does this discourse act through and upon subjects (how are peacekeepers, men and women represented? How do peacekeepers enact their knowledge of "gender" in their missions?)? It is worth pointing out that the latter point will focus solely on the expectations of how peacekeepers should behave in their work. Indeed, as my thesis is limited to discourse analysis, it does not allow observations about the ways peacekeepers put the training into practice.

I also use Shepherd's 'analytical strategies' to frame my analysis. Shepherd builds on Foucault's work to provide a specific method for analysing discourse, which I will in turn use to construct my methodology. Shepherd undertook to analyse the UN Security Council Resolution 1325 on 'Women, Peace and Security'. She uses a double-reading strategy, which involves proceeding from a descriptive to an analytical reading. Secondly, she seeks to unravel the meanings of 'nodal points', the

$8 \quad$ Michel Foucault, The Archaeology of Knowledge, Trans. Am Sheridan Smith (London: Tavistock Publications Limited, 1972). Shepherd, Gender, Violence and Security: Discourse as Practice.

$9 \quad$ Foucault, The Archaeology of Knowledge, Trans. Am Sheridan Smith. 
centre signifiers around which she organises her analysis. Finally, she examines how objects and subjects are produced, represented and legitimated.

Building on Shepherd's work, as I will explain in more length later, my thesis aims to interrogate and deconstruct the concept of 'gender-awareness' in the UN training material. In order to achieve this goal, I chose to build my analysis around three dominant discursive sites or 'nodal points' that I take as starting points. These are: [1] 'how the relations between women and men are structured' (gender), [2] 'how they are affected by violent conflict' (gender and violence), and [3] 'how the mere presence of peacekeepers further impacts on those relations' (gender, violence and security). ${ }^{11}$

I selected these three nodal points to construct my analysis because they represent the learning objectives and main messages of the training toolkit. Analysing discourse through these discursive sites provides a suitable open framework for gradually introducing notions of violence and security and how they relate to gender. Also, this strategy provides an opportunity for identifying objects (of knowledge about gender in peace and security, i.e. what is produced as truth) and the way that (dominant) subjects (such as male peacekeepers and women) are positioned in the UN discourse.

Using both Foucault's and Shepherd's work as an analytical framework, this thesis is an attempt to answer the following research questions: "how is the discourse of gender-awareness constructed through UN gender-training material for peacekeepers? How does this discourse contribute to shaping representations of gender, violence and security?" With these research questions, I intend to look at what the discourse of gender-awareness is; how women and peacekeepers are positioned in this discourse; and what male peacekeepers need to be aware of in the realm of gender, violence and security (which in turn produces a 'normal

\footnotetext{
10 The 'nodal points' will be explained in further detail in my methodology section. Shepherd, Gender, Violence and Security: Discourse as Practice.

11 United Nations Department of Peacekeeping Operations, Gender and Peacekeeping Operations in-Mission Training. Introduction iii.
} 
expected behaviour' from them).

To help answer my research questions, I have divided the thesis into several chapters. The first chapter will set out my analytical framework and my methodology. I intend to explain how I use discourse in my analysis and how I build my methodology on both Foucault's and Shepherd's work.

In the second chapter, I will first review the literature that addresses the construction of feminities and masculinities in war and peace. This will show that women are constructed as being 'peacemakers' and that their feminity is shaped as being 'peaceful' and as 'mother of the nation'. This will lead me to review the literature that shows how militarised masculinities are shaped through war. Secondly, I will review the literature that explores the ways in which gender has been integrated (or mainstreamed) into UN policies, which will demonstrate how gender has been thought of as a synonym for women, hence reducing the potential that a real investigation on gender could have on peace operations. ${ }^{12}$

In the third chapter, I will combine the methodology I set out in Chapter 1 and the conclusions of the literature review to interrogate the notion of 'gender-awareness' in the UN training material. My analysis will be constructed around the three nodal points I previously introduced. The research will show that 'gender-awareness' as a discourse in the UN gender-training material is composed of: [1] gender that equates 'sex' and 'women', [2] the dichotomy between women positioned as 'victims' and men as 'heroes' (expected normal behaviour), and [3] universals such as women's rights, which ignore cultural contexts in their approach to gender.

Finally, the end of the third chapter will further investigate the discourse of 'genderawareness training, which I argue has been established as a 'tool' in the military field, but not as a critical concept (reminding us of Foucault's disciplinary technology). This tool seeks to produce understanding (knowledge) of gender, violence and security, and to control and regulate its agents' (male peacekeepers')

12 Shepherd, Gender, Violence and Security: Discourse as Practice. 
behaviours.

Therefore, this thesis will interrogate the discourse of gender-awareness in terms of the production of traditional stereotypes of feminities and masculinities in war and peace. It will ask whether the UN concept of gender training is truly challenging the way the UN has previously been 'doing' and understanding gender. The thesis will eventually draw conclusions about the implications of the discourse of 'genderawareness' in the politicisation of gender and women. 


\section{Chapter 1}

\section{ANALYTICAL FRAMEWORK AND METHODOLOGY}

In this chapter, I set out my analytical framework and my methodology, which build on both Michel Foucault's notion of discourse and Laura Shepherd's "analytical strategies”."3 By way of introduction, this chapter outline the Foucauldian notion of power and how it interrelates to knowledge (as a regime of truth), which is embedded in discourse. I shall then provide the reader with an explanation of how discourse is used in this thesis, through Foucault's and Shepherd's work. Thirdly, I intend to show how Shepherd's method builds on Foucault's work and explain her analytical strategies as a way of analysing discourse. ${ }^{14}$ Finally, I explain my methodology, which logically comes out of Foucault's and Shepherd's work.

\section{Foucault's power and knowledge}

I first intend to introduce Foucault's notion of power and how it closely relates to knowledge as the formation of a 'universalising truth'. I will show that the Foucauldian notion of power produces 'subjects' that are categorised, easily identified and normalised. The normalisation of subjects is rendered possible through the establishment of 'disciplinary regimes' or 'technology'. Discipline allows the formation of 'docile bodies' and the regulation of behaviours and produces knowledge (what we know as being the truth). Finally, knowledge is embedded in discursive practice, as it will be exemplified.

It is important to distinguish Foucault's power from the traditional Hobbesian understanding of power, upon which realism has drawn. For Hobbes, people agree to give up a portion of their freedom to a sovereign, called the Leviathan, in order to

\footnotetext{
13 Foucault, The Archaeology of Knowledge, Trans. Am Sheridan Smith, Shepherd, Gender, Violence and Security: Discourse as Practice.

$14 \quad$ Laura Shepherd uses the term 'analytical strategies' and I will stick to her terminology. This term refers to a tripartite methodology that she created to analyse discourse. I will attempt to explain what her analytical strategies actually are in one of the sections of this chapter.
} 
find peace and security. ${ }^{15}$ From the Hobbesian notion of sovereignty, power is defined as "the ability to make people (or things) do what they would not otherwise have done". ${ }^{6}$ This implies that there is someone, an A, who has an effect on another person, a B: A has the ability to persuade $\mathrm{B}$ to make decisions and undertake actions in the manner that A wants. ${ }^{17}$

Foucault, on the other hand, envisages a notion of power that gets rid of A and B. He considers how power fluctuates through and towards people and how power is associated with bodies of knowledge (or discourse). ${ }^{18}$ What Foucault calls 'governmentality' or 'biopower' seeks to regulate life and normalise population through statistics, control, public health and so on. ${ }^{19}$ The realist's and Foucauldian's forms of power are often opposed, in that the former has "the right to take life or let live", whilst the latter has "the power to make live and let die". 20

Further, the Foucauldian notion of power produces 'subjects': "[power] acts in a relatively autonomous way and produces subjects just as much as, or even more than, subjects reproduce it. [...]. Subjection [refers to] the processes of the construction of subjects and as a collection of techniques or flows of power which run through the whole of a particular social body". ${ }^{21}$ In other words, certain kinds of 'subjectivity' (such as being a prisoner) are (re)produced through power. ${ }^{22}$ This new way of seeing power suggests that power no longer comes solely out of political

\footnotetext{
15 Thomas Hobbes, Leviathan, ed. C. B. Macpherson (Baltimore: Penguin Books [1968], 1961 Reprint). Hobbes calls the situation in which there is no sovereign the 'state of nature' ("solitary, poor, nasty, brutish and short"). The Leviathan is a sovereign ruler-body politic comprised of everyone who has given up their right.

${ }^{16}$ Iain McLean and Alistair McMillan, Oxford Concise Dictionary of Politics (New York: Oxford University Press, 2003), 431.

17 Ibid. This conception of power has accompanied the rise of sovereignty. There are two distinct forms of sovereignty, absolute and popular, but both have in common their relationship with law.

18 Michel Foucault, Power. Ed. James D. Faubion (New York: New Press, 2000).

19 Steven Epstein, "An Incitement to Discourse: Sociology and the History of Sexuality," Sociological Forum 18, no. 3 (2003), 494.

20 Michel Foucault, Society Must Be Defended, op. cit., p. 241.

21 Alec McHoul and Wendy Grace, A Foucault Primer: Discourse, Power and the Subject (Malaysia: Melbourne University Press, 1993), 22.

22 Michel Foucault, Discipline and Punish: The Birth of the Prison. 1977, Trans. Alan Sheridan (New York: Vintage, 1995).
} 
structures and the law but acts on the "conduct of individuals". ${ }^{23}$ Also, it defines the individual differently. While in the realist's definition of power the individual is defined as being a rational actor (and passive object) in the exercise of sovereignty, biopower positions the subject as having multiple identities (and bodies).

Studying individuals as subjects revolves around a new way of seeing the world and is tied to truth and knowledge (or self-knowledge). Foucault explains that "this form of power that applies itself to immediate everyday life categorizes the individual, marks him by his own individuality, attaches him to his own identity, imposes a law or truth on him that he must recognize and others have to recognize in him”. 24 In other words, being 'an individual' (or a subject) is not something natural, but it is shaped through and within society. The formation of identities allows categorisation and recognition by others. If one does not fit into these categories, one becomes categorised as 'abnormal' or 'deviant' (e.g. homosexuals). Hence power is productive and revolves around how 'we' see ourselves and the world. ${ }^{25}$ This concept will be of great importance when studying the formation of peacekeepers as subjects.

To further examine how power acts through and towards subjects, Foucault analysed the formation of prisons in France in the early $19^{\text {th }}$ century and examined how the authorities controlled and imposed a "regime of truth" on individuals. ${ }^{26}$ 'Discipline' refers both to punishment and to the institution of a set of skills that must be acquired to master a particular field, and is particularly important for the purpose of this research, which is to analyse the discursive practices that come out of (gender) training for peacekeepers in the military (peace and security) field. ${ }^{27}$

\footnotetext{
$23 \quad$ Foucault, Power. Ed. James D. Faubion, 341.

24 Ibid., 331.

25 Geoff Danaher, Tony Schirato, and Jen Webb, Understanding Foucault (Australia: Allen \& Unwin, 2000).

$26 \quad$ Foucault, Discipline and Punish: The Birth of the Prison. 1977. Foucault refers to the 'panopticon', which is a prison that is shaped as a tower and allows guards to see their prisoners but doesn't allow the prisoners to know they are being watched. This form of surveillance is not particular to prison but is reproduced in modern societies (with the installation of cameras in the streets, for example). It contributes to the shaping of individuals' behaviour as they know they can be watched.

27 Danaher, Schirato, and Webb, Understanding Foucault.
} 
Technology or 'tactics' are elaborated to ensure the coordination and control of the whole mechanism (such as a surveillance procedure). ${ }^{28}$ Hence 'disciplinary technology' produces a certain kind of subject (associated with a certain kind of behaviour) that can be easily identified (e.g. prisoner, soldier). ${ }^{29}$ Discipline is therefore concerned with the production of 'docile' bodies that can be easily regulated..$^{30}$ It further contributes to the 'normalisation' of behaviours (that become universalised and incontestable models of truth). ${ }^{31}$

The regimes of truth that are constructed through disciplinary technology are tied to the production of knowledge. Further, both truth and knowledge "authorise and legitimate the workings of power". ${ }^{2}$ Knowledge is created through the diverse discursive practices that exist in a society. Andersen points out that "power is present in our approach to things insofar as the objects we relate to are always discursive objects, produced by and in discourse". ${ }^{33}$ Hence, ('objects' of) knowledge is embedded in discourse, or what Foucault calls discursive practice. Indeed, Foucault "conceives the objects of knowledge as emerging from the relationships in a society that produce the discursive practices within which the 'objects' are embedded. [...] A Foucauldian analysis is therefore interpretative in its orientation; it seeks to elucidate the meanings of foundation of knowledge". ${ }^{34}$ Discourse and bodies of knowledge are interrelated and embedded in each other, which lead Foucault to look for the meanings that come from and construct knowledge.

Thus, I have introduced [1] the relationship between power and knowledge, [2] how it produces a certain kind of subject and normalises behaviours and [3] how

\footnotetext{
28 McHoul and Grace, A Foucault Primer: Discourse, Power and the Subject, 70-71.

29 Danaher, Schirato, and Webb, Understanding Foucault, 49.

30 Ibid., 50.

31 Margaret A. Paternek, "Norms and Normalization: Michel Foucault's Overextended Panoptic Machine," Human Studies 10, no. 1 (1987).

32 Danaher, Schirato, and Webb, Understanding Foucault, 64.

33 Niels Åkerstrom Andersen, Discursive Analytical Strategies: Understanding Foucault, Koselleck, Laclau, Luhmann (Policy Press, 2003), 3.

$34 \quad$ Michael J Shapiro, Language and Political Understanding: The Politics of Discursive Practices (New Haven, London: Yale University Press, 1981), 148.
} 
knowledge is embedded in discursive practices. I now expand further on how discourse is used as a site of struggle in this analysis and this will be illustrated through Foucault's and Shepherd's work.

\section{Discourse as a site of struggle}

As I have outlined through Foucault's notion of power, discourse is concerned with both bodies of knowledge and disciplinary practices. It forms a 'site of struggle' in which truth-knowledge and social controls are mutually inclusive. They are inclusive of each other because disciplinary technology controls individuals and their bodies to produce the only adequate behaviour (truth). I will now try to explain how Foucault's and Shepherd's work on discourse provides me with a solid methodology to undertake a discourse analysis.

For this thesis, I use a (Foucauldian) notion of discourse that entails both language and social practice. By discourse, Foucault means "a group of statements which provide a language for talking about - a way of representing the knowledge about a particular topic at a particular historical moment...Discourse is about the production of knowledge through language. But...since all social practices entail meaning, and meanings shape and influence what we do - our conduct - all practices have a discursive aspect". ${ }^{35}$ Put simply, 'discourse' is not only made up of words (as in language or text) but embodies broader cultural contexts and social practices. As shown before, discourse as a site of struggle is understood as (social) practices, which entail meanings and are productive of knowledge.

Whilst Foucault is usually referred to as a post-structuralist, his work draws on the fact that discourse is not a structure. Indeed, as Andersen explains, structuralism is a concept that seeks to 'deconstruct' texts and meanings by looking at their hidden parts: "underneath the visible, directly accessible text, lays a slightly displaced

\footnotetext{
35 Stuart Hall, Representation: Cultural Representations and Signifying Practices (Sage
} Publications Ltd, 1997), 44. 
invisible text that controls the questions and answers posed by the visible text". ${ }^{36}$ For Foucault, however, only the level of the visible - or the 'apparent' - belongs to the notion of discourse; there is no underlying structure. ${ }^{37}$ In other words, meanings do not come from an underlying hidden part of a statement, rather meanings emerge from a group of statements that belong to a social practice (how they relate to each other, their irregularities and dispersions).

Furthermore, a Foucauldian notion of discourse produces insiders and outsiders. As Andersen explains, "Foucault wants to show how any discourse involves excluding procedures, which not only exclude themes, arguments and speech positions from the discourse, but also produce outsiders, denounce groups of people as sick, abnormal or irrational, and grant other groups the right and legitimacy to treat these people". ${ }^{38}$ Andersen draws on the fact that as discourse produces a model of truth, therefore it produces a kind of subject that either conforms or deviates from this model. The subjects who conform to the model created are normalised (i.e. they are 'normal'), while those who deviate are ab-normalised (i.e. they are abnormal, deviant).

The production of certain kind of subjects with normalised behaviours is called a 'regime of truth'. These regimes of truth seem natural and unquestionably true. Foucault says that "every utterance is an utterance within a specific discourse to which certain rules of acceptability apply”. Similarly, A.B. Fetherston argues that "the power of discourse is to render 'right', 'legitimate', 'taken-for-granted', 'natural' specific ways of knowing, acting and organizing social life... Crucially, this rendering of 'right' silences other possibilities (they are unknowable since they are not possible)" ${ }^{39}$ This quote means that discourse exists within a set of institutionalised

\footnotetext{
36 Andersen, Discursive Analytical Strategies: Understanding Foucault, Koselleck, Laclau, Luhmann, 2.

$37 \quad$ Ibid., 2 and Shapiro, Language and Political Understanding: The Politics of Discursive Practices, 132-134.

38 Andersen, Discursive Analytical Strategies: Understanding Foucault, Koselleck, Laclau, Luhmann, 3.

39 A.B. Fetherston cited by Sandra Whitworth, Men, Militarism, and UN Peacekeeping: A Gendered Analysis (Lynne Rienner Publishers, 2004), 28.
} 
practices that are produced and reproduced through time: discursive formations or practices "delimit the range of objects that can be identified, define the perspectives that one can legitimately regard as knowledge, and constitute certain kinds of persons as agents of knowledge, thereby established as norms". ${ }^{\circ}$

In other words, discourse produces certain kinds of subjects that are 'agents of knowledge', established as representing a universalised truth (that is qualified as a discursive norm). ${ }^{41}$ I intend to use Foucault's agents of knowledge as a site of authority for my topic, i.e. I will look at who the peacekeepers are in the UN training material, how they are meant to behave in the field of peace and security and how they are expected to enact their knowledge of gender in their actions. The discourse of 'gender-awareness' (that I will explain in more depth later) seeks to produce the peacekeeper subject as a male agent of knowledge.

Borrowing from Foucault's notion of discourse, Shepherd uses what she calls "discourse-theoretical analysis" (DTA), which I will in turn use for my research. For Shepherd, the primary goals of DTA are to "identify, problematize and challenge". Shepherd greatly emphasises the debt she owes to Foucault, Laclau and Mouffe, and Derrida in constructing her methodology. She highlights the fact that her approach is deconstructive. Shepherd takes "deconstruction to be 'a reading which is sensitive to what is irreducible in every text, allowing the text to speak before the reader, and listening to what the text imposes on the reader",. 43 She borrows from Foucault's archaeological analysis, which looks at what is 'apparent' in a discursive formation, by looking at how statements (or groups of signs) are constructed through

\footnotetext{
40 Shapiro, Language and Political Understanding: The Politics of Discursive Practices, 130.

$41 \quad$ Note here that 'norm' is employed in a Foucauldian way, as something 'normal', which carries a universal truth in it - I will refer to it as 'discursive norm'. It is different from the 'norm' that is discussed by constructivist authors. See, for example, Peter J. Katzenstein, The Culture of National Security: Norms and Identity in World Politics (Columbia Univ Press, 1996). Martha Finnemore, "Norms, Culture, and World Politics: Insights from Sociology’s Institutionalism," International Organization 50, no. 2 (1996). Alexander Wendt, "Anarchy Is What States Make of It: The Social Construction of Power Politics," International Organization 46, no. 2 (1992).

$42 \quad$ Shepherd, Gender, Violence and Security: Discourse as Practice, 32.

43 Ibid., 26.
} 
'regularity and dispersion. ${ }^{44}$ This means looking at how statements appear, i.e. which statements are repeated and dispersed to form a discursive logic.

For Foucault, statements only exist in a discourse, and discourse analysis consists of "the compilation of all actual statements (spoken and written) in their historical dispersion and in their specific momentary value." ${ }^{45}$ Analysing and constructing the archive involves examining how the statements appear, not what ('is the meaning') or why ('this statement'). Archaeological discourse analysis creates objects, which are constructed, classified and identified, as well as positioning subjects. ${ }^{46}$

As I have previously outlined, objects refer to 'objects of knowledge' (bodies of knowledge) and subjects refer to 'agents of knowledge' (agents that embody the truth, i.e. normalised behaviour). In this study, objects of knowledge refer to the construction of feminities and masculinities in war and peace, whilst subjects refer to the peacekeepers, who are meant to represent a normalised version of feminities and masculinities. Shepherd, too, undertakes to examine how discourse is productive of bodies of knowledge as well as positioning subjects. She uses the 'critical concepts' of gender, violence, security and the international, and shows how they relate to specific discourses. She then explores the "regimes of truth that claim to fix their meaning" through DTA. ${ }^{47}$

I have introduced Foucault's notion of discourse, which [1] is understood as social practices, which entail meanings and are productive of knowledge, [2] involves looking at the 'archive', or group of statements, that is constructed through regularity and dispersion, and [3] produces objects (of knowledge) and subjects (agents), both of which embody a regime of truth, hence excluding those who do not behave the right way. I have also outlined how Shepherd's DTA builds on Foucault's notion of discourse as she takes a deconstructive approach and looks for

\footnotetext{
$44 \quad$ Foucault, The Archaeology of Knowledge, Trans. Am Sheridan Smith.

45 Andersen, Discursive Analytical Strategies: Understanding Foucault, Koselleck, Laclau,

Luhmann, 13.

$46 \quad$ Ibid., 8-16.

47 Shepherd, Gender, Violence and Security: Discourse as Practice. This paragraph as a whole refers to Shepherd's strategies, 26-33.
} 
the regimes of truth that are carried through discourse.

Both Foucault's and Shepherd's work will help answer my research questions, as they provide me with a solid methodology. I will investigate the UN gender-training material as (social) practices, looking at how statements appear (their regularities and dispersions) and how it produces objects and subjects that embody a certain regime of truth. I will explain my methodology further, but before I do that, I need to clarify Shepherd's specific analytical strategies, from which I borrow extensively.

\section{Shepherd's analytical strategies}

Shepherd undertakes to analyse the UN Security Council Resolution (UNSCR) 1325, on 'Women, Peace and Security' through DTA and I have outlined how her work builds on Foucault's discourse. More specifically, she uses what she calls 'analytical strategies', which allow her to structure her work. I now look at these analytical strategies, which are composed of three main elements. First, she uses a 'doublereading' strategy, which involves proceeding from a descriptive to an analytical reading. Secondly, she undertakes to unravel the meanings of 'nodal points', which are the centre signifiers around which she organises her analysis. Thirdly, she examines how objects and subjects are produced, represented and legitimised. I adapt Shepherd's analytical strategy to my methodology, as I will explain further.

Shepherd employs what she calls a 'tripartite' discourse analysis to identify "practices of (re)production, (re)presentation, and (re)legitimization in the document itself'. ${ }^{48}$ The tripartite DTA is a strategy that uses 'double reading, 'nodal points' and 'subject-positioning. First, the 'double-reading' strategy involves using a descriptive and then an analytical reading in a deconstructive process. This double task allows her to uncover the meanings of 'nodal points' or 'master signifiers', which do not have fixed meanings prior to the deconstructive work. ${ }^{49}$ A nodal point is a centre that produces a discourse around which the "field of discourse" or the discursive formation takes place. Shepherd takes as main nodal points the fields of

\footnotetext{
$48 \quad$ Ibid., 26.

49 Ibid., 27-28.
} 
gender, violence, the international, and security. She explores how "these signifiers are ordered within the texts so as to inscribe a meaningful relationship between them". $5^{\circ}$ In other words, she looks at how the signifiers of 'gender, violence, security and the international' are productive of a discourse, and then at how these discourses interrelate to each other to produce a 'discursive formation'.

A discursive formation is the overall discourse which embodies different discourses (such as the discourse of gender and violence in Shepherd's work). In my analysis I will examine the discursive formation of 'gender-awareness' and then 'genderawareness training, which are made up of discourses of gender, security and violence.

Shepherd's third strategy focuses on the production, representation and legitimisation of objects and subjects, and how they relate to each other. For instance, she examines the ways violence is represented and shows that violence is produced "as legitimate, as gendered, as threatening to civil society [...]. These representational practices are 'articulatory' as they establish a 'relational complex"'. ${ }^{1}$ She illustrates her example by showing that the 'discursive elements' (violence and legitimation) are articulated together ("there are times when violence is legitimate"), which contributes to changing the identity of the discursive elements ("so not all violence is bad") ${ }^{52}$ - hence contributing to the formation and positioning of objects (of knowledge) and subjects (agents).

Through this tripartite discourse analysis strategy (double reading, nodal points and subject-positioning), Shepherd aims to deconstruct the text and its representational practices, which makes "a sense of order in the texts, thus constructing the meaning of the concepts with which [she is] concerned". ${ }^{33}$ Her methodology coincides with the Foucauldian archaeological analysis that seeks regularity and dispersion in

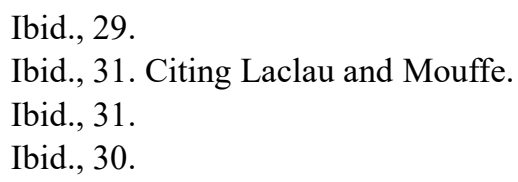


statements, as I have previously highlighted. Another element that coincides with Foucault's archaeological work is found in Shepherd's intention to look for coherence in the texts within a set of limits: "in order to be comprehensible, discourses must conform to the temporary boundaries of a given discursive field". Her boundaries are fixed by the (discursive) fields of 'gender, violence, security and the international'. In this thesis, the boundaries are fixed by the fields of gender and violence, with some implications for the field of security.

Citing Foucault, Shepherd explains this coherence as being "the various rhetorical schemata according to which groups of statements may be combined (how descriptions, deductions, definitions, whose succession characterizes the architecture of the text, are linked together)". ${ }^{55}$ Hence she examines how the statements appear, such as the linking of their different elements, which forms the discursive formation (or architecture). Shepherd explains further: "in the identification of representational practices specific to gender, for example, I look for instances of gendered identities described 'as' or 'like', statements about gendered identities that can be problematized and emphasis on aspects of gender provided by placement within the text and/or repetition". ${ }^{56}$ She looks at how gender (for example) is represented in the (UNSCR 1325) text and how statements that address gender identity are repeated or dispersed so as to form a discursive logic.

Thus, I have shown that Shepherd's analytical strategies are made up of three main elements: [1] double reading, [2] 'nodal points' around which discourses are produced, and how these nodal points (and their discourse) relate to each other, and [3] the production, representation and legitimation of objects (of knowledge) and subjects (agents). I have illustrated how her analytical strategies relate to Foucault's archaeological analysis. I now undertake to explain to the reader how I borrow both from Foucault's work and Shepherd's analytical strategies to construct my methodology.

\footnotetext{
$54 \quad$ Ibid., 29.

55 Ibid., 29. Emphasis as in original.

56 Ibid., 30.
} 


\section{Applied methodology}

Following from the outline I have given of Foucault's notion of discourse and Shepherd's analytical strategies, I formulate how I intend to use their work to help answer my research questions. I have already introduced how I use discourse (i.e. as social practices and productive of knowledge), which is composed of the 'archive' (regular and dispersed groups of statements) and which produces objects and subjects that embody a regime of truth, hence relating discourse-knowledge to power.

I propose to examine the (social and representational) practices that form the UN gender-training discursive formation, and how they contribute to the formation of knowledge about the way gender relates to peace and security. More specifically, I will interrogate how 'gender-awareness training' is constructed as a discursive formation that embodies elements of truth (knowledge) in the way gender, violence and security interrelate. As such, I intend to look at how the UN discursive practices on gender in peacekeeping are productive of rules that are further established as 'discursive norms', and how 'agents of knowledge' are constituted (and who they are).

Keeping in mind Foucault's and Shepherd's methods, I will look at the way statements appear; that is their regularity and dispersion. This involves looking at how gender appears through three nodal points (that I will explain further) in groups of statements, such as in pictures, in practical exercise materials, in PowerPoint slides and in definitions used in the Gender and Peacekeeping Operations In-Mission Training toolkit. The research will show irregularity in the discursive formation of the UN; that is the presence of a double language in the way the material presents itself and the meanings that are unravelled through analysis.

I will use Shepherd's tripartite analytical strategies; that is, 'double reading', 'nodal points', and 'subject-positioning'. Using a 'double reading', I will first undertake a descriptive reading of the training package to establish what it is aimed at accomplishing, and how the material presents itself in its approach to gender and 
training (also with a focus on violence and security). Secondly, I will go on to an analytic reading that seeks to unravel the meanings of statements.

As I have already partially explained, Shepherd takes as nodal points 'gender', 'violence', 'the international', and 'security'. This research thesis cannot embody all four nodal points as sole master signifiers as this would go beyond the scope of this project. Instead, I will focus on aspects of gender and look at how gender is constructed with violence and security.

For this research, the nodal points (or master signifiers) that I have chosen represent the three main messages/objectives given by the UN gender-training tool. The introductory part of the Gender and Peacekeeping Operations In-Mission Training toolkit stresses that "without an understanding of [1] how the relations between women and men are structured, [2] how they are affected by violent conflict and [3] how the mere presence of peacekeepers further impacts on those relations, there can be little meaningful advance in the effectiveness of peacekeeping operations".57

I have taken these three interrogations as starting (nodal) points for discourse analysis:

- The first nodal point, 'how the relations between women and men are structured (gender)', will allow for a discussion of how the UN represents both the differences between sex and gender, and the link between gender and culture (or the social and cultural construction of gender norms).

- The second nodal point, 'how [gender is] affected by violent conflict (gender and violence)', will allow for positioning men and women (with a focus on the representations of peacekeepers) as subjects in the UN discourse. The UN language on the social context in which gendered roles and responsibilities are reshaped by violent conflict will be examined.

- The third nodal point, 'how the mere presence of peacekeepers further impacts on [gendered] relations (gender, violence and security)', will allow

\footnotetext{
$57 \quad$ United Nations Department of Peacekeeping Operations, Gender and Peacekeeping Operations in-Mission Training. Introduction, iii.
} 
the establishment of the UN discourse on gender training in the security realm, and how it seeks to bring basic skills to peacekeepers, which serves to recognise the positive and negative impacts of peacekeepers' actions on the community. It will show that gender-awareness has been raised as a new discursive norm, i.e. a norm that fixes (male) peacekeepers' behaviours (the agents).

Analysing discourse through these three nodal points will allow me to gradually introduce notions of violence and security and how they relate to gender. As such, the first nodal point will focus solely on aspects of gender. The second nodal point will address the notion of gender and how it relates to violence. The third nodal point will uncover meanings related to gendered-based violence and security. This strategy will allow me to identify both objects (of knowledge, i.e. what is produced as truth) and the way that subjects (male peacekeepers and women) are positioned in the UN discourse.

Before proceeding to the discourse analysis of the UN concept of 'gender-awareness' in training peacekeeping, I now undertake to review the literature of two major areas relevant for this research. First, I will review the literature which addresses gender, violence and security. Secondly, I will review the literature which covers the UN gender policies (UNSCR 1325) in peace and security. It is important to indicate to the reader that I focus only on aspects relevant to this research. Indeed, the literature encompasses a broad range of ideas and concepts, especially on the individual aspects of 'gender', 'violence' and 'security'. As it would be beyond the scope of this project to review the literature of each concept separately, I will examine aspects that address the interconnection between the concepts. 


\section{Chapter 2 LITERATURE REVIEW}

Before examining how 'gender-awareness' is constructed in the UN training policies for peacekeepers, I first determine why it is important to integrate gender (and gender training) into the UN peace and security policies, and how gender has been incorporated into UN policies so far, through a review of the literature.

I will first review the literature that addresses the construction of feminities and masculinities in war and peace. ${ }^{58}$ It will show that women have long been constructed as 'peacemakers' in politics, which contributes to shaping their feminities as being 'peaceful' and as 'mother of the nation'. This construction does not allow for women's agency in war to be recognised as they are still being marginalised. It doesn't consider how traditional gendered roles and responsibilities are disrupted and reshaped through (violent) armed conflict.

Secondly, I will review the literature that explores the formation of masculinities in war. I will demonstrate that a discourse of (hegemonic) militarised masculinities emerges in conflict, which is further established as being the 'truth' (knowledge) that acts upon and through the military field. It creates 'soldiery' subjects that behave in a (violent) masculine way; hence excluding women (and feminity) from the field and forcing women to behave in a masculine way, too.

Thirdly, I will review the literature that explores the ways gender has been integrated (or mainstreamed) into the UN policies. It will show that gender has been mainstreamed as [1] a way of promoting gender equality, hence a way of increasing women's representation and participation, and [2] a way of protecting women from

\footnotetext{
58 "Gender is a term used in contrast to sex, to draw attention to the social roles and interactions between women and men, rather than to their biological differences. Gender relations are social relations, which include the ways in which men and women relate to each other beyond that of personal interaction. They include the ways in which the social categories of male and female interact in every sphere of social activity, such as those which determine access to resources, power, and participation in political, cultural and religious activities." Donna Pankhurst, ed. The 'Sex War'and Other Wars: Towards a Feminist Approach to Peace Building, Development, Women, and War: Feminist Perspectives (Oxford: Oxfam GB, 2004), 26.
} 
gender (sexual)-based violence, that further contributes to representing women as 'vulnerable., 59 I will argue (with Shepherd) that gender has been thought of as a synonym for women, hence reducing the potentiality that a real investigation on gender could have on peace operations. ${ }^{60}$ Gender is thought of in a quantitative manner (i.e. including 'more' women), which reduces women's potentiality for better representation and participation in peace and security. ${ }^{61}$

\section{Gender, violence and security}

I examine how gender has been related to and constructed with violence and security through a review of the literature. I will focus especially on the formation of gender roles that emerge in war and peace. From the literature review, I argue that the traditional women/men dichotomies are further reinforced in the discourse of war and peace; that is, women are constituted as being peacemakers, cultural bearers of the nation, while men are constructed as being soldiers and heroes. Both discourses form a Foucauldian notion of what is established as being the truth (knowledge) and contribute to shaping subjects (male peacekeepers/women) and how they should behave, either in a 'feminine' or 'masculine' way.

\section{1- Construction of (peaceful) feminities: women as peacemakers}

From the literature review, the dominant discourse of 'feminities' in war and peace comes from the belief that women are natural 'peacemakers'. This is problematic as it relies on the assumption that this identity is due to essential (biological) characteristics that women possess. Further, this belief doesn't consider the disruption of traditional roles in war and the fact that women are active participants in both war and peace.

In situations of war and armed conflict, gender stereotypes are profoundly accentuated. Cynthia Cockburn highlights the fact that "it's true that in the patriarchal family system women are primarily valued as mothers, a function

\footnotetext{
59 Shepherd, Gender, Violence and Security: Discourse as Practice.

60 Ibid.

$61 \quad$ Ibid.
} 
represented as biological and natural, and in nationalistic and militaristic versions of patriarchal ideology the significance of child-bearing and child-rearing is elevated to perverse levels, with women represented as the reproducers of the people and guarantors of its collective culture". ${ }^{62}$ Hence the traditional dichotomy between man/breadwinner/protector of the family and woman/mother/vulnerable is reinforced in the discourse in war. At the same time, other imageries appear in times of conflict, which associate men with heroes and women with peacemakers.

Feminities have traditionally and culturally been described as the opposite of masculinities, that is, embodying passivity and non-violence as the main characteristics of their subjectivities. ${ }^{63}$ This conceptualisation of feminities relates to the place of the 'mother' as central in the family and in society, the mother being the cultural bearer of the nation. ${ }^{64}$ Hence women have been constructed as being inherently and essentially more peaceful than men, that is, able to bring peace in a war-torn society. As the International Alert's Code of Conduct affirms, "we explicitly recognise the particular and distinctive peacemaking roles played by women in conflict afflicted communities". ${ }^{65}$ It is because of the peaceful qualities associated with women that the UN has decided to include them in peace activities, as it will be explained further.

However, this conceptualisation is problematic as it assumes that women as women are inherently more peaceful. Indeed, it is hard to see how essential feminine qualities such as non-violence and kindness can truly be attributable to women due to their sex. Goldblatt and Meintjes have shown that women can also inflict terrible tortures on other women and participate in the organisation of prostitution: "many South African women supported apartheid, firmly convinced that racism and

\footnotetext{
62 Cynthia Cockburn, From Where We Stand: War, Women's Activism and Feminist Analysis (London, New York: Zed Books, 2007). 210.

63 Donna Pankhurst, "The 'Sex War' and Other Wars: Towards a Feminist Approach to Peace Building," Development in Practice 13, no. 2-3 (2003).

$64 \quad$ Ibid.

65 Ibid., 162.
} 
violence were necessary to ensure order and to maintain a particular way of life".66 Their research shows that women can be the perpetrators of violence too.

Furthermore, conflicts contribute to changing and inverting gendered social roles and responsibilities within the community. Women are no longer housewives but assume more responsibilities during and after the conflict. ${ }^{67}$ Both men and women are exposed to new threats that need to be addressed. Angela Mackay shows that "men leave, die in combat, are brutalised, lose employment, or resort to despair, violence, or apathy. Women assume enormous burdens of work and all manner of different tasks and responsibilities, they lose their security and their protectors, and they are also victimised and marginalised". 68 Thus war has a significant impact on gender and transforms the traditional social roles within the community. Men can no longer assume their role of breadwinners and protectors, and women must take on more responsibilities. The change of traditional gender roles in war explains why peacekeeping and peace-building missions must take these gender variables into account in their work.

Indeed, the dichotomy "man does, woman is" ceases to be applicable during wartime, as several feminist writers have demonstrated. ${ }^{69}$ In fact, women are actively engaged in conflicts and assume all kinds of responsibilities. Meredith Turshen argues that "in modern forms of war, especially civil wars and wars of liberation, women are also combatants; women resist and fight back; they take sides, spy, and fight among themselves; and even when they don't see active service, they often support war efforts in multiple ways, willingly or unwillingly". ${ }^{70}$ Turshen takes as an example Ugandan women who were members of the National Resistance

\footnotetext{
66 Beth Goldblatt and Sheila Meintjes, eds., South African Women Demand the Truth, What Women Do in Wartime: Gender and Conflict in Africa (London; New York: Zed Books Ltd, 1998), 43-45. 67 Meredeth Turshen, ed. Women's War Stories, What Women Do in Wartime: Gender and Conflict in Africa (London; New York: Zed Books Ltd, 1998), 20.

68 Mackay, "Training the Uniforms: Gender and Peacekeeping Operations", 218.

69 Turshen, ed. Women's War Stories. And see also: Cockburn, From Where We Stand: War, Women's Activism and Feminist Analysis.

$70 \quad$ Turshen, ed. Women's War Stories, 1.
} 
Army (NRA) and spied during the 1980 s civil war. ${ }^{71}$ Laura Shepherd also demonstrates that "there is significant literature concerning women's involvement with violence and oppression; 'feminists in the North and South [have] challenged the so-called peaceful nature of women by examining their involvement in national liberation struggles, their direct and/or indirect support of armed conflicts and their contributions to war and militarism generally' (El Jack 2003: 12)" ${ }^{72}$ Women's active involvement in conflicts is indisputable, yet their participation is barely acknowledged and is quickly forgotten once conflicts end, which means they are marginalised.

The community, along with international organisations such as the $\mathrm{UN}$, is quick to forget about women's contribution to war, i.e. women's participation in the realm of 'high politics'. Teckla Shikola was a soldier during the Namibia war and explains how she experienced the conflict in her testimony. She confesses that "the civilians really suffered, particularly women and children, but after the war, no one mentioned the contributions women made during the liberation struggle. [...] Men appreciate women who cook for them, and they respect women who fought in the war with them, but after independence, they didn't really consider women as part of the liberation movement" ${ }^{73}$ This example shows that women's agency in war is not recognised, as their subjectivity is confined to a certain model of what it is to be 'feminine' (and this does not encompass fighting or participating in war). Women are relegated to the realm of peace, however, by being categorised as 'peacemakers' because of their sex, they are 'superficially' included. This aspect will be discussed further in the analysis in Chapter 3.

Because women's various subjectivities in war are ignored, they remain remarkably unrepresented in peace-building processes, and their needs are not as well met as those of male soldiers in post-conflict reconstruction. ${ }^{74}$ In particular, women's

\footnotetext{
$71 \quad$ Ibid., 1.

72 Shepherd, Gender, Violence and Security: Discourse as Practice, 89.

73 Teckla Shikola, ed. We Left Our Shoes Behind, What Women Do in Wartime: Gender and Conflict in Africa (London and New York: Zed Books Ltd,1998), 148.

74 Pankhurst, ed. The'sex War'and Other Wars: Towards a Feminist Approach to Peace Building. 17.
} 
security is no longer made a primary concern when conflict ends, although it often coincides with an increase in domestic violence. Further, women often suffer from the traumatic effects caused by the (sexual) violence that they went through during wartime. However, they receive low rates of assistance, insufficient healthcare and a low level of encouragement to speak out, which is an essential step in the successful prosecution of the aggressors. ${ }^{75}$ In addition, women soldiers are not integrated into rehabilitation programmes and do not benefit from the same support as men.

The non-representation of women in post-conflict reconstruction and rehabilitation both highlights and produces a politics of securitisation that seeks to return to "normal" (i.e. meaning as before, when the gender roles were traditional and definite). Donna Pankhurst shows that the pressure of accepting changes in gender relations is greater in periods of peace than in periods of war, so that "the ideological rhetoric is often about 'restoring' or 'returning to' something associated with the status quo before the war, even if the change actually undermines women's rights and places women in a situation that is even more disadvantageous than it ever was in the past". ${ }^{76}$ Along the same lines, Megan MacKenzie demonstrates that women and girl combatants in Sierra Leone have not been integrated into programmes for the rehabilitation of soldiers. MacKenzie argues that "throughout the process of prioritizing security interests in Sierra Leone, the concerns of women have consistently been ranked not only out of the category of security, but also out of the category of 'normal politics' [as high politics]". 77 The return to a 'normal' peaceful - place is inherently symbolised by women because of their status of householders and mothers, hence explaining why they are left out of any securitisation/rehabilitation programmes.

I have explored the issues associated with the categorisation of women as inherently more peaceful than men through the literature review. This discourse (embedded

\footnotetext{
$75 \quad$ Ibid., 17.

76 Ibid., 19.

77 Megan MacKenzie, "Reconstructing Women? Post-Conflict Security and the Return to "Normal" in Sierra Leone" (paper presented at the Canadian Political Science Association Annual, 2007).
} 
in the constituted knowledge of 'what it is to be feminine') contributes to further excluding women from the realm of politics. This phenomenon contributes to creating and reinforcing images of militarised masculinities, as I undertake to demonstrate now. ${ }^{78}$

\section{2- Formation of (hegemonic) militarised masculinities}

I now review the literature that addresses men's roles in war. From the literature, it becomes clear that a discourse of (hegemonic) militarised masculinities has long dominated the military field, hence the field of peace and security. ${ }^{79}$ It creates a certain image of what it is to be a soldier who needs to behave in a (violent) masculine way - hence excluding women (and feminity) from the field and forcing them to behave in a masculine way if they want to be included in the field.

War allows for different (male) soldiers' subjectivities to take place. Sandra Whitworth examines the formation of masculinities in war in depth and argues that "soldiers are not born, they are made; and part of what goes into the making of a soldier is a celebration and reinforcement of some of the most aggressive, and most insecure, elements of masculinities: those that promote violence, misogyny, homophobia, and racism". ${ }^{80}$ She goes on to explain that soldiers have been subjected to "the ideology of manliness" and that they have been told what it is to be a good soldier. Turshen argues further that "war creates militarized societies, and an elaborate ideology of gender roles links masculinity to militarism. [...] The military is a male preserve, run by men and for men according to masculine ideas of male bonding, male privilege, and militarist values derived from definitions of masculinity". ${ }^{81}$ Therefore being a soldier is associated with masculine images of the military, hence excluding women from the field.

\footnotetext{
78 Elisabeth Prugl, "Gender and War: Causes, Constructions, and Critique," Perspectives on Politics 1, no. 02 (2003).

79 Hegemony refers to a term invented by Antonio Gramsci, which illustrates the dominance of one class over another. I refer to this term now because it is used a lot in the literature that I reviewed. However, for the purpose of this research, I will prefer talk about 'discourse' and how it has been universalised. Robert W. Cox, "Gramsci, Hegemony and International Relations: An Essay in Method," Millenium: Journal of International Studies 12, no. 2 (1983).

80 Whitworth, Men, Militarism, and UN Peacekeeping: A Gendered Analysis, 3.

81 Turshen, ed. Women's War Stories, 5.
} 
The subjectivities of soldiers are inherently associated with the gender roles that emerge in the social and cultural context of security. In the field of security, Cohn demonstrates that the culture of defence is highly masculine. If a woman wants to be part of it, she must learn how to speak a specific 'hyper-masculine' language (that Cohn calls 'technostrategic ${ }^{82}$ ). As Cohn points out, the (sexual) imageries that take place in the nuclear world do not come from the individual but emerge from a "broader cultural context" ${ }^{\prime 3}$ (which in this case is defence and security). These imageries are used to 'domesticate' nuclear weapons, i.e. to detach them from their first goal, which is to end lives. By humanising weapons and making them their principal 'subject', the nuclear world does not include human death in its vocabulary (deaths are referred to as 'collateral damage'). ${ }^{84}$ The masculinity of the nuclear/defence world is expressed through detachment from emotions in discourse. What Cohn's study shows is that the role of gender emerges from a cultural context in which security must be 'performed' in a masculine/violent way (hyper-masculine) and is constructed through discourse and social practices (that are produced and reproduced).

Masculinities have been institutionalised in the military, which makes them more resistant to change. R.W. Connell stresses that "the institutionalization of masculinity is a major problem for peace strategy. [...] Collective struggle, and the re-shaping of institutions, including military and police forces, are as necessary as the reform of individual life". ${ }^{85}$ Indeed, the military is one of the institutions in which the cultural processes of masculinity and patriarchy have had the most influence. Cynthia Enloe shows how forms of militarism have been introduced into society, persuading men and women of its inevitability and naturalness. ${ }^{86}$ Cynthia

\footnotetext{
82 Carol Cohn, "Sex and Death in the Rational World of Defense Intellectuals," Signs 12, no. 4 (1987). 
Cockburn also points out that "war as institution is made up of, refreshed by and adaptively reproduced by violence as banal practice, in the everyday life of boot camp and battlefield. Masculinity in its various cultural forms is an important content of that cycle: masculinity shapes war and war shapes masculinity". ${ }^{87}$ In other words, war is embedded in the cultural constitution of masculinities, which in turn impacts on the discursive practices of war (as productive of 'how war should be').

The cultural construction of masculinities and gender identities in war entails the suppression of emotions, which at the same time renders war 'possible'. Indeed, the suppression of emotions is a sine qua non condition of the discourse of war, which embodies bravery (self-control) and discipline (obedience). ${ }^{88}$ Elisabeth Prugl, reviewing Goldstein's work, explains that this “appeal to masculine identity help[s] overcome men's reluctance to go to war and help[s] produce a functioning army. Men are not inherently disposed to war; instead, they most often need to be dragged kicking and screaming in to [war], constantly brainwashed and disciplined once there, and rewarded and honoured afterwards". ${ }^{89}$ Thus, masculinities in war are rendered possible by the suppression of emotions; hence making emotions belong to the realm of feminities - the private.

Furthermore, the construction of masculinities is cultural. Enloe shows that the warrior identity is central to the formation of Serbian imagined masculinity, and this in turn produces ideals of feminity that are complementary. ${ }^{90}$ She argues that to understand the mass rape of Muslim women in Serbia between 1991 and 1993, one must interrogate how militarised masculinities have emerged alongside the nationalist discourse. ${ }^{91}$ Enloe explains that in many societies, "cultural construction[s] of masculinity [...] have been dependent not simply on celebrating

\footnotetext{
87 Cockburn, From Where We Stand: War, Women's Activism and Feminist Analysis, 248.

88 Prugl, "Gender and War: Causes, Constructions, and Critique".

89 Ibid.

90 Cynthia Enloe, ed. All the Men Are in the Militias, All the Women Are Victims: The Politics of Masculinity and Femininity in Nationalist Wars, The Women and War Reader (New York, London: New York University Press, 1998).

$91 \quad$ Ibid.
} 
men as soldiers, but on simultaneously elevating women as mothers-of-soldieringsons, valuing women chiefly for their maternal sacrifices for the nations". ${ }^{22}$ Thus nationalism must be understood along with how notions of masculinities and feminities are simultaneously and culturally shaped. Research has shown that there is a cross-cultural notion of what masculinities are (called 'cultural constructions of manliness' by Turshen), and that war contributes to shaping militarised masculinity in many different cultural contexts - hence forming (hegemonic) militarised masculinities. ${ }^{93}$

The formation of (hegemonic) militarised masculinities further impacts on women, who tend to adopt masculine behaviour to fit into the militarised culture and identity. Megan Bastick, Karin Grimm and Rahel Kunz argue that "women are not 'by their nature' more gender-aware, nor will women always push for gender reforms Women entering a predominantly 'masculine' environment tend to react accordingly by adopting 'masculine' behaviour. There are examples of female officers being tougher on rape victims than male colleagues to prove themselves. Women also feel marginalised by the dominant 'masculine' culture and therefore do not 'dare' to bring up gender issues". ${ }^{94}$ Thus it seems that women (soldiers) adopt the principal traits of the gender-masculine identity in war.

I have reviewed the literature that addresses how notions (discourse) of feminities and masculinities emerge in war. Women are perceived as essentially more peaceful than men, while men are perceived as being violent and embodying 'manly' (aggressive) characteristics. These discourses form feminities and masculinities that are culturally constituted and that feed each other. These discourses are tied to knowledge and power, that is, they both create a discourse (knowledge) of what it is to be a woman and a man in war and contribute to shaping masculinity as a dominant ideology in the military and political field. As discourse-knowledge is

\footnotetext{
92 Ibid., 54.

93 Pankhurst, "The 'Sex War' and Other Wars: Towards a Feminist Approach to Peace Building." 168. See Turshen, ed. Women's War Stories.

94 Bastick, Grimm, and Kunz, Sexual Violence in Armed Conflict: Global Overview and Implications for the Security Sector. 148
} 
embedded in power, it explains that men are included in the political (peace and security) field, while women are excluded from its realm.

I shall now examine how the UN has integrated gender in its peace and securityrelated policies. For this research, I will mostly focus on the UN Security Council Resolution 1325 on women, peace and security, and how it has constructed a certain notion of gender (related to violence and security).

\section{The UN gender policies in peace - UNSCR 1325}

I now undertake a review of the literature that concerns the integration of gender (or gender mainstreaming) in UN peace operations. I will focus on analyses of the UNSCR 1325, which will eventually help answer my research questions and contribute to illuminating and strengthening my findings. As I have mentioned, this research owes a great debt to Shepherd's analysis of UNSCR 1325, both in terms of her methodology ('analytical strategies') and in terms of her findings as to the way gender has been constructed by the UN, which further (inter)relates with violence and (international) security discourses. ${ }^{95}$ I will discuss two predominant critiques of the UN gender mainstreaming in security and peace (UNSCR 1325), which have been extracted by Shepherd. ${ }^{96}$

The literature shows that gender mainstreaming has been used by the UN [1] as a way of acting on women's representation and participation (hence mainstreaming 'women', not gender), and [2] as a way of protecting women from gender(sexual)based violence (hence representing women as 'vulnerable'). As will be shown, these discursive aspects draw on the formation of feminities as 'peaceful' and masculinities as 'militarised' and 'violent' that I have previously explained.

Shepherd argues that gender has been constituted as a 'variable' (such as in 'gendersensitive training efforts', 'gender-based violence', gender dimensions', 'gender

95 Shepherd, Gender, Violence and Security: Discourse as Practice.

96 Ibid. 
considerations') that can be easily replaced by the word 'women.' 97 The UN seems to be dealing with the gender concept in a quantitative manner, as being synonymous with including more women in its business. By doing so, the UN is equating (and reducing) women's 'participation' to women's 'representation.9 Further, women are represented as 'vulnerable' and victims that need to be protected by (men) soldiers. $^{99}$

\section{1- Gender mainstreaming: promoting gender equality}

I first intend to explain how the notion of gender mainstreaming has progressively been introduced into the UN policies in peace and security. Gender mainstreaming comes from the recognition that armed conflict affects men and women differently. ${ }^{100}$ This concept mainly arose out of an increase in awareness about the gender(sexual)-violence that women undergo in war. The concept of 'mainstreaming' gender has the potential to subject all the UN policies to the particular interests of men and women, and in this sense could be quite powerful. ${ }^{101}$ It assumes that gender is a social construct and acknowledges the different resources and access to power available to men and women. ${ }^{102}$ Hence mainstreaming gender into all of the UN operations has been made a priority, with the goal of achieving a gender parity of $50 / 50 .{ }^{103}$ While it is important to acknowledge that this is an important step towards a better treatment of women in policies, the way gender has been constituted is problematic, as it mostly focuses on women and their 'peaceful' characteristics. Gender mainstreaming hence equates with mainstreaming women so that they are more represented. ${ }^{104}$ However, representation has only been

\footnotetext{
$97 \quad$ Ibid., 120.

98 Ibid.

$99 \quad$ Ibid.

100 Whitworth, Men, Militarism, and Un Peacekeeping: A Gendered Analysis.

101 Ibid., 124.

102 Ibid., 124.

103 Judith H. Stiehm, "Women, Peacekeeping and Peacemaking: Gender Balance and Mainstreaming," International Peacekeeping 8, no. 2 (2001), 42.

104 Purkarthofer, "Gender and Gender Mainstreaming in International Peacebuilding". And Joanne Dow, "Mainstreaming Gender or Mainstreaming Women? - a Feminist Critique of UNSCR 1325" (Thesis submitted in partial fulfillment of the requirements for the Master of International Relations - Victoria University of Wellington, 2008).
} 
thought of in terms of achieving a 'critical mass', which does not ultimately allow women to be represented in a meaningful way. ${ }^{105}$

The UN first started talking about the advancement of women and the importance of gender mainstreaming in 1995 at the Beijing Conference. The Beijing Plan (or Platform for Action) promoted gender equality as essential for effective peacebuilding operations and suggested a set of measures to be taken to encourage the representation of women. ${ }^{106}$ The Beijing Conference is usually considered to be a significant step in recognising the importance of mainstreaming gender in all areas of work at the UN, and in the field of security; this is a recognition that has continued to gain traction. The conference was followed by the Windhoek Declaration (or the Namibia Plan) in 2000 on 'Mainstreaming a Gender Perspective in Multidimensional Peace support Operations', which "demands effective gender mainstreaming as a standard component of all peace support missions". ${ }^{107}$ It sought to promote gender equality and an awareness of the implications of gender in peace activities.

Following from the Windhoek Declaration, The UN Security Council Resolution 1325 on "Women, Peace and Security" was adopted by the UN in October 2000 and addressed for the first time the position of women in war, both in terms of the violence they suffer from and of their contribution in periods of conflict. ${ }^{108}$ It set international standards for assimilating gender in conflict resolution and reconstruction. UNSCR 1325 calls for action in three main areas: [1] the promotion of equality and women's participation in peace and security, [2] the recognition and protection of women from gender-based violence and, finally, [3] the mainstreaming of gender in all aspects of conflict prevention and reconstruction

\footnotetext{
105 Shepherd, Gender, Violence and Security: Discourse as Practice.

106 Purkarthofer, "Gender and Gender Mainstreaming in International Peacebuilding".

107 Tarja Vayrynen, "Gender and UN Peace Operations: The Confines of Modernity," International Peacekeeping 11, no. 1 (2004), 136.

108 Shepherd, Gender, Violence and Security: Discourse as Practice. And also: Purkarthofer, "Gender and Gender Mainstreaming in International Peacebuilding". See also Krause, "Women in Peace and Conflict? The Need of Female Representation and Participation." Whitworth, Men, Militarism, and Un Peacekeeping: A Gendered Analysis.
} 
(including the areas of peacekeeping, peace-building, post-conflict reconstruction, humanitarian aid and disarmament). ${ }^{109}$ As for the first aim, it is based on the assumption that women seem more approachable to the local population. ${ }^{110}$ Also, women who have been subjected to aggression or raped by a male soldier find it less threatening to deal with a woman than another man in uniform. ${ }^{111}$ Furthermore, research has shown that the presence of women soldiers has an impact on the gender-based violence of male soldiers. ${ }^{112}$ Thus the presence of women contributes to legitimising the activities undertaken by peace operations amongst local communities. $^{113}$

These mandate, and UNSCR 1325, promote gender mainstreaming as synonymous with gender equality (as mainstreaming women). The UN states that "mainstreaming a gender perspective is the process assessing the implications for women and men of any planned action, including legislation, policies and programmes, in all areas and at all levels. [...] The ultimate goal is to achieve gender equality". ${ }^{114}$ The UN has expressed great interest in the role women play in situations of conflict and peace reconstruction and seeks to promote the equal participation of both sexes. As the text of UNSCR 1325 states: "reaffirming the important role of women in the prevention and resolution of conflicts and in peace-building, and stressing the importance of their equal participation and full involvement in all efforts for the maintenance and promotion of peace and security, and the need to increase their role in decision-making with regard to conflict prevention and

\footnotetext{
109 http://unscr1325.org/. Accessed 25/01/2010.

110 Louise Olsson, "Mainstreaming Gender in Multidimensional Peacekeeping: A Field Perspective," International Peacekeeping 7, no. 3 (2000), Sabrina Schulz and Christina Yeung, eds., Private Military and Security Companies and Gender, Gender and Security Sector Reform Toolkit (Geneva: DCAF, OSCE/ODIHR, UN-INSTRAW,2008), 4.

111 Krause, "Women in Peace and Conflict? The Need of Female Representation and Participation.".

112 Ibid. See also: Olsson, "Mainstreaming Gender in Multidimensional Peacekeeping: A Field Perspective".

113 Schulz and Yeung, eds., Private Military and Security Companies and Gender. Some other authors have shown their enthusiasm as to UN SCR 1325 such as Hudson, "En-Gendering UN Peacekeeping Operations".

114 Louise Olsson, "Gender Mainstreaming in Practice: The United Nations Transitional Assistance Group in Namibia," International Peacekeeping 8, no. 2 (2001), 98.
} 
resolution" 115 UNIFEM (the United Nations Development Fund for Women) explains that this paragraph aims to encourage measures that directly impact on "the number of women in decision-making position". ${ }^{116}$ Shepherd argues that the inclusion of women, as encouraged in the UNSCR 1325, is purely based on a quantitative approach and seeks to achieve a better "critical mass". ${ }^{117}$ Indeed, realising a better representation of women does not necessarily lead to "improvements in the lived experience of other individuals". ${ }^{118}$ Shepherd criticises the fact that representation (as adding more women) is equated with participation. $^{119}$

While this could certainly represent potential for women, basing women's representation on numbers contributes to further reproducing gender inequalities. ${ }^{120}$ This is partly because the UN discourse on gender is still based on sexual-difference theory, and is mainly concerned with "women”. Feminist authors have shown how gender is not meaningfully incorporated into peace-operation processes as it is not gender that is mainstreamed but women. ${ }^{121}$ Hence, the UN seeks to include women in peace operations because of their qualities of being women. Once again, the UN focuses on the fundamental biological differences between men and women, which constructs specific values and characteristics that women should possess, such as being nurturers (mothers), promoting and representing peace, and being "inherently pacifist". ${ }^{122}$ Laura Shepherd argues that

\footnotetext{
115 (UNIFEM).

116 Ibid., emphasis added.

117 Shepherd, Gender, Violence and Security: Discourse as Practice. Some authors, however, such as Louise Olsson, have shown the positive impact of achieving a 'critical mass' in peacekeeping operations, such as mobilising more local women and contributing to change some of the stereotypical gender representations. See Olsson, "Mainstreaming Gender in Multidimensional Peacekeeping: A Field Perspective".

118 Shepherd, Gender, Violence and Security: Discourse as Practice, 117.

119 Ibid.

120 However, the goal that the UN has set remains difficult to achieve in peacekeeping missions. See, for example, Olsson, "Gender Mainstreaming in Practice: The United Nations Transitional Assistance Group in Namibia" and Stiehm, "Women, Peacekeeping and Peacemaking: Gender Balance and Mainstreaming".

121 See Dow, "Mainstreaming Gender or Mainstreaming Women? - a Feminist Critique of UNSCR $1325^{\prime \prime}$.

122 Shepherd, Gender, Violence and Security: Discourse as Practice, 118.
} 
"the discursive construction of [the] feminized peacemaker" is apparent in the analysis of the Secretary-General Report and the UNSCR 1325, as shown in "women play an active role in informal peace processes (UNSC 2002 a:13)" and women can be "actors in early warning, reconciliation, peace-building or post-conflict resolution (UNSC 2004a: 112)". ${ }^{123}$ Thus the UN Report and SCR 1325 keep essentialising women based on their feminine attributes, hence legitimising their claim for more women's contribution in peace activities.

\section{2- Protecting women: women as 'vulnerable'}

At the same time, the UN represents women as 'vulnerable', 'suffering/lacking' and 'victims'. Both UNSCR 1325 and the Secretary-General Report referred to women as being 'vulnerable' and discussed "the protection, rights and the particular needs of women". 124 Shepherd argues that "the representational strategies in the Reports suggest that it would be valid to reduce these articulations to their simplest form [that is] 'women and girls are vulnerable' (UNSC 2002a:7). [...] Thus, the universal subordination of women is affirmed through the predication of feminity as vulnerability and the positioning of feminity as "low". ${ }^{125}$ In other words, women are constituted as inferior, as vulnerable creatures that need masculine protection. Hence, women are perceived as embodying essentialist feminine values that are inferior to those carried by men. Not only are women 'mothers' and 'peacemakers', but it seems that in the UN discourse they are also 'lacking' (something) and "always more in need". ${ }^{126}$ Shepherd states that "the representation of women in the [UN] Report minimizes female agency, articulating a feminine subject position that in times of conflict is either 'forced out' or 'pushed into' dangerous situations. Women lack: they suffer from 'lack of land...lack of access to, or control over, resources (UNSC 2002a: 9)."127

Thus, the UN discourse on women prevents women from being 'actors' and active

\begin{tabular}{ll}
\hline 123 & Ibid., 89. \\
124 & Ibid. \\
125 & Ibid., 87. \\
126 & Ibid., 88. \\
127 & Ibid., 87.
\end{tabular}


participants in times of conflict. Women's agency is reduced to what they are lacking and what they need to be provided with. Their strengths are not recognised. Susan McKay demonstrates that "women and girls are usually rendered invisible or are, at best, marginalised by being perceived only as leaders and facilitators of cultural and social reconstruction”." ${ }^{128}$ McKay exemplifies her argument by showing that the girls that fought in Mozambique and Sierra Leone did not benefit from any of the disarmament, demobilisation and reintegration programmes (DDR). ${ }^{129}$ Similarly, Megan MacKenzie shows that the DDR process in Sierra Leone, despite a considerable number of women combatants, was largely "gender-blind" and that women and girls were relegated to the roles and identities of "'camp followers', 'abductees', 'sex slaves', 'domestic slaves', 'or girls and women associated with the fighting forces' and 'vulnerable groups associated with armed movements",." ${ }^{130}$ These examples show that the participation of women in war and the recognition of female fighters is denied in the UN discourse and that women's agency is reduced to 'followers' or 'slaves' - hence women do not benefit from the same rehabilitation programmes as men.

Even when the role of women in conflict and post-conflict reconstruction is finally acknowledged, feminist authors have criticised the UN's incapacity to tell 'which women' are parts of these processes. In other words, women are constructed as a 'women's group' and there is no distinction between the different roles they might play. Shepherd states: "as Carol Cohn, Helen Kinsella and Sheri Gibbengs argue, 'it remains important to ask which women are included and are we expecting more from women (super heroines) than we expect of men?' (2004: 136, emphasis in original)". ${ }^{131}$ Pankhurst further reiterates that "denying women agency is also a potential outcome of the crude deployment of a 'gender' concept in policy, where

\footnotetext{
128 Susan McKay, ed. Reconstructing Fragile Lives: Girls'Social Reintegration in Northern Uganda and Sierra Leone, Gender, Peacebuilding, and Reconstruction (Oxford: Oxfam focus on gender,2005), 23.

129 Ibid., 25.

130 MacKenzie, "Reconstructing Women? Post-Conflict Security and the Return to "Normal" in Sierra Leone".

131 Shepherd, Gender, Violence and Security: Discourse as Practice, 90.
} 
all women are presumed to act in the same way and are powerless to do otherwise."132 The UN has failed to recognise that there are different categories of women, and expectations concerning women's role in peace activities are not entirely defined.

In conclusion, whilst the UN's policies of reducing gender inequality should certainly be acknowledged, the UN has failed to think of gender beyond 'numbers', which ultimately contributes to further reproducing inequality. By including more women in their business, the UN suggests that women-as-women can impact positively on the 'macho-masculine' soldier's culture, which will eventually ricochet into gendered-based violence. ${ }^{133}$ However, the UN has not recognised that the mere presence of more women does not equate to a reduction in gender-based violence.

The UN needs to reform its approach on gender and adopt a critical one that engages with the formation of militarised masculinities in war and conflicts. Many feminist authors discuss the UN's lack of critical thinking about gender and the formation of militarised masculinities in war, peace and security. Sandra Whitworth argues that "gender critiques have been forced to fit into the UN's 'way of doing business"” without transforming how that business is done. This kind of incorporation of gender is ultimately a more effective way of silencing critique compared to straightforward dismissal, because it ensures that deeper critical questions, those that look, for example, at militarised masculinity, do not end up on formal agendas for addressing gender and peacekeeping" ${ }^{134}$ The UN has failed to engage with deeper issues on gender in periods of conflict, which ultimately prevents the organisation from changing its approach on gender to one that could impact positively on armed conflicts and peace. As such, the UN discursive practices of gender, violence and security further reproduce the dichotomies between 'peaceful' feminity and 'aggressive' masculinity that I have previously highlighted.

\footnotetext{
132 Pankhurst, "The 'Sex War' and Other Wars: Towards a Feminist Approach to Peace Building", 169.

133 Bastick, Grimm, and Kunz, Sexual Violence in Armed Conflict: Global Overview and Implications for the Security Sector, 174. They show that some research has suggested the positive impact of women's presence.

134 Whitworth, Men, Militarism, and Un Peacekeeping: A Gendered Analysis, 17.
} 
From this review of the literature, I have discussed the different ways the UN has attempted to mainstream gender in peace and security, and I have shown how mainstreaming gender relates to discursive practices about the ways feminities and masculinities are constructed, embedded in knowledge (about gender, violence and security) and power (that acts upon and through the behaviour of individuals).

However, there is no (or little) literature that takes a critical perspective on gender implementation, that is, on gender training in peace operations. The literature that addresses gender training deals with practical issues (or challenges) and generally celebrates gender training as being a good initiative, a step forward for the advancement of gender and women. ${ }^{135}$ This thesis challenges the assumption that analysing discursive practices should stop at the level of policies without exploring further how discourse could be (re)produced through the implementation of policies.

Furthermore, while the concepts of 'gender mainstreaming' and 'gender equality' have been extensively addressed in the literature, showing how they are sites of discourse embedded in power, not much has been said on the concept of 'genderawareness' (which is directly tied to the idea of how gender policies are implemented). ${ }^{136}$

I shall now undertake a discourse analysis, using the methodology that I have outlined in my analytical framework, to unravel meanings related to gender, violence and security arising from 'gender-awareness' training in UN peacekeeping.

\footnotetext{
135 See, for example, Hudson, "En-Gendering UN Peacekeeping Operations".

136 Of course, the literature has discussed the importance of 'training awareness' on gender (see, for example, Enloe, ed. All the Men Are in the Militias, All the Women Are Victims: The Politics of Masculinity and Femininity in Nationalist Wars). Lene Hansen, "The Little Mermaid's Silent Security Dilemma and the Absence of Gender in the Copenhagen School", Millennium: Journal of International Studies 29, no. 2 (2000). But I haven't encountered any literature that addresses how the UN shapes 'gender-awareness' as a concept.
} 


\section{Chapter 3}

\section{ANALYSIS OF ‘GENDER-AWARENESS’ DISCOURSE}

I now undertake the discourse analysis, following the methodology I have outlined. I will interrogate the notion of 'gender-awareness' in the UN training material and how it is constructed around three dominant discursive sites (that, following Shepherd's analytical strategies, I have called nodal points): [1] 'how the relations between women and men are structured' (gender), [2] 'how they are affected by violent conflict' (gender and violence), and [3] 'how the mere presence of peacekeepers further impacts on those relations' (gender, violence and security). ${ }^{137}$ I will examine how the UN discursive practices through training produce what to be aware of in the realm of gender, violence and security.

The analysis will show that 'gender-awareness' as a discourse within UN gender training is composed of: [1] gender that equates 'sex' and 'women', [2] gender training in relation to violence that reproduces the dichotomy between women as 'victims' and men as 'heroes', and [3] gender skill-sets in relation to violence and security that emphasise universals such as women's rights and ignore cultural contexts in their approach to gender.

I will then explore gender training further as a tool (or a technology) that (re)produces the traditional stereotypes of feminities and masculinities that have been discussed in the literature review, by shaping subjects' behaviours.

\section{Contextualising gender training in peacekeeping}

In this section, I aim to explain the institutional and political context surrounding the development and implementation of gender training in peace-support operations. This will show that gender training was born from the UN policies that have been discussed in the literature review, such as UNSCR 1325. In addition, I will

\footnotetext{
137 United Nations Department of Peacekeeping Operations, Gender and Peacekeeping Operations in-Mission Training. Introduction, iii.
} 
discuss the conditions for the emergence and implementation of gender training (and its challenges). This will illustrate the usefulness and relevance of problematising gender training through the lens of 'gender-awareness' as a concept that can potentially transform the way gender has been done in peace and security.

Gender-training toolkits and resources have emerged over the past ten years following calls by the UN to develop and implement gender training in peacesupport operations. These initiatives mostly originated from two international mandates; the Windhoek Declaration and the Namibia Plan of Action (2000), and the UN Security Council Resolution 1325 on women, peace and security (2000). The Namibia Plan of Action demands that gender issues be mainstreamed "throughout all regional and national curricula and courses for peace support operations, particularly those sponsored directly by the Training Unit of DPKO”. ${ }^{138}$ UNSCR 1325 recognises "the importance of... specialized training for all peacekeeping personnel on the protection, special needs and human rights of women and children in conflict situations”." The resolution seeks to encourage states to develop such training in their pre-deployment and in-mission operations, using as an argument the preventative impact that gender training could have on rates of sexual exploitation and abuse. ${ }^{140}$ Furthermore, gender training echoes the belief that a "peace" that does not fulfil the needs of the community but instead contributes to the inferiorisation and reduction of women's roles within such a community is not worth having. ${ }^{141}$

What makes gender training of relevance now is that men are (finally) included in the process of gender mainstreaming: "in the 2004 Report, men are mentioned: 'Training on gender issues should be provided to all staff at decision-making levels,

\footnotetext{
138 Lyytikäinen, "Gender Training for Peacekeepers: Preliminary Overview of United Nations Peace Support Operations", 6.

139 Bastick, Grimm, and Kunz, Sexual Violence in Armed Conflict: Global Overview and Implications for the Security Sector, 172, and also: (UNIFEM).

$140 \quad$ Bastick, Grimm, and Kunz, Sexual Violence in Armed Conflict: Global Overview and Implications for the Security Sector. 172.

141 Mackay, "Training the Uniforms: Gender and Peacekeeping Operations" and Lyytikäinen, "Gender Training for Peacekeepers: Preliminary Overview of United Nations Peace Support Operations".
} 
men as well as women' (UNSC 2004a: 97). [...] the Report allows for the suggestion that readers might be forgiven for thinking that gender is just about women. As Terrell Carver (1996) has succinctly remarked, 'gender is not a synonym for women', but nevertheless 'we slip from gender to women and women to gender but have yet to slip form gender to men"”. ${ }^{142}$ In this analysis, I will interrogate how men are included in the gender-training package and what it means for the relationship between gender, security and violence.

Following from these mandates, the United Nations DPKO, the United Nations Institute for Training and Research (UNITAR), and other peacekeeping training centres have developed gender-training packages designed for both military and civilian police personnel. A notable example of this is the Gender and Peacekeeping Online Training Course, developed by the UN Department of International Development (DFID) and the Canadian Department of Foreign Affairs and International Trade (DFAIT) in 2000. ${ }^{143}$ The online course proposes a three-day training programme, which contains plenty of resources (exercises, methodologies, readings...), and covers different themes, such as gender and culture, humanitarian law, human rights, and gender in peacekeeping. ${ }^{144}$ However, this course has been criticised for being too academic and not being sufficiently targeted to the intended audience. $^{145}$

Canada's Pearson Peacekeeping Centre has also integrated UN standards into its training modules for military and police and has mainstreamed gender into its training programmes. ${ }^{146}$ Within the UN, UNITAR conducted a programme on the Special Needs of Women and Children in and after Armed Conflict for civilian personnel in eight peacekeeping missions between 2001 and 2006, but this was

\footnotetext{
142 Shepherd, Gender, Violence and Security: Discourse as Practice, 91.

143 http://www.genderandpeacekeeping.org/.

144 Ibid.

145 Lyytikäinen, "Gender Training for Peacekeepers: Preliminary Overview of United Nations Peace Support Operations", 10.

146 Bastick, Grimm, and Kunz, Sexual Violence in Armed Conflict: Global Overview and Implications for the Security Sector, 172.
} 
eventually suspended for budget reasons. ${ }^{147}$ Finally, the DPKO has been very proactive in developing material that includes a gender component. They have developed a comprehensive gender tool, Gender Resource Package for Peacekeeping Operations (2004), which explains the concept of gender mainstreaming to peacekeeping personnel (military, civilian police and civilian) of all grades. ${ }^{148}$ To complement the resource package, DPKO has designed two other pre-deployment training modules that are included in their Standardized Generic Training Modules (SGTM): SGTM 17 and SGTM ${ }_{5} \mathrm{C}^{149}$ In addition, in 2001 DPKO implemented a tool designed specifically for in-mission training, the Gender and Peacekeeping InMission Training tool, which delivers training on the meaning and implications of gender in peace operations. ${ }^{150}$

As I have already mentioned, this thesis aims to analyse DPKO's Gender and Peacekeeping In-Mission Training package. The DPKO undertook three concrete measures to integrate gender analysis in peace operations. The first consisted of the creation of a gender unit along with the appointment of a gender advisor on each mission. The second action sought to increase the number of women involved in peacekeeping operations. The third measure aimed to provide "gender-awareness training to all peacekeeping personnel". This research focuses on the last aspect, and the terms "gender-awareness training" will be examined and put in perspective through discourse analysis. According to DPKO, the Gender and Peacekeeping Training package aims to facilitate the implementation of gender mainstreaming by achieving three main goals: defining how the relationships between men and women are structured; explaining the social context in which gender roles and responsibilities are transformed by armed conflict; and making peacekeepers aware

\footnotetext{
147 Lyytikäinen, "Gender Training for Peacekeepers: Preliminary Overview of United Nations Peace Support Operations", 10.

148 United Nations Department of Peacekeeping Operations, Gender Resource Package For Peacekeeping Operations.

149 Lyytikäinen, "Gender Training for Peacekeepers: Preliminary Overview of United Nations Peace Support Operations".

$150 \quad$ United Nations Department of Peacekeeping Operations, Gender and Peacekeeping Operations in-Mission Training.

151 Lyytikäinen, "Gender Training for Peacekeepers: Preliminary Overview of United Nations Peace Support Operations", 6.
} 
of their actions by facilitating the development of basic skills in gender analysis. ${ }^{152}$

In other words, gender training has been set up as a concept that seeks to include "briefings to clarify key gender terms (such as the difference between sex and gender) and to identify and challenge gender stereotypes. This involves challenging pre-conceived notions that, for example, women are more peaceable and will automatically use less force than men and exploring links between models of masculinity and violent behaviour. Gender training is a forum to discuss the different ways in which men and women experience security, and to build the capacity of the participants to respond appropriately to the needs of men, women, boys and girls" ${ }^{153}$ Hence the gender-training concept seeks to reform socially and culturally fixed conceptions of gender and this involves interrogating and potentially changing the ways of seeing gender. These objectives sound attractive and this research aims to look at whether the UN DPKO training material is indeed challenging (cultural) gender stereotypes s or contributing to their (re)productions.

What is more, The DPKO specified that its training package should be re-tailored according to the specific needs of the in-mission peacekeeping being carried out, to consider the cultural, historical and local contexts of the missions. ${ }^{154}$ It is therefore expected that the trainers will collect local data to adapt the content of the training package. However, it is not always easy for trainers to collect such data, as the evaluation of the training sessions in the UN Mission in the Democratic Republic of Congo (MONUC) shows. ${ }^{155}$ Also, and as I will exemplify in my analysis, not enough room is left in the DPKO training package for the adaptation of 'genderawareness' to local cultures.

The first field experiences have shown that gender training faces many challenges.

\footnotetext{
152 Ibid., 7, see also Nadine Puechguirbal, "Gender Training for Peacekeepers: Lessons from the Drc," International Peacekeeping 10, no. 4 (2003), and United Nations Department of Peacekeeping Operations, Gender and Peacekeeping Operations in-Mission Training.

153 Bastick, Grimm, and Kunz, Sexual Violence in Armed Conflict: Global Overview and Implications for the Security Sector, 148.

154 Puechguirbal, "Gender Training for Peacekeepers: Lessons from the DRC", 116.

155 Ibid., 116.
} 
The packages are criticised for being too complex and sophisticated to be fully grasped by military and civilian police peacekeepers. Indeed, peacekeeping personnel tend to confound gender with women's issues and do not understand the relevance of such training for their work. ${ }^{156}$ Further, the training brings up emotional, linguistic and cultural issues about the ways peacekeepers have always seen and understood the world and it can be intensely challenging to bring up new perspectives on gender identities and roles. ${ }^{157}$ Another challenge is that predeployment training for peacekeepers suffers from a lack of time, preparation and in-depth learning, which potentially undermines its relevance. Some have argued that ongoing training on gender at all levels and in all areas of peacekeeping missions must be pursued. ${ }^{158}$ In this, Norway is a good example of how to practise gender training throughout the general training of peacekeepers. ${ }^{159}$ Finally, gendertraining modules have limited impact, as there is not yet any system for monitoring peacekeepers and holding them accountable. ${ }^{160}$ All these challenges are important to keep in mind. However, gender training can have a powerful impact in contributing to challenging and transforming traditional perspectives on gender.

This research does not seek to examine the different challenges arising from the (practical) implementation of the gender-training material. However, this paper assumes that the training material can have a significant impact on raising awareness about the ways gendered relations are structured and about how armed conflict contributes to further impacting on such relations. Gender training has the potential to transform the way gender is understood in peace operations and to challenge the ways gender is currently done. It has the potential for rethinking how gender, violence and security are constructed around prevailing notions of militarised masculinities. By problematising gender training through the concept of 'gender-awareness', I seek to uncover what raising awareness actually means for

\footnotetext{
156 Ibid., 117.

157 Lyytikäinen, "Gender Training for Peacekeepers: Preliminary Overview of United Nations Peace Support Operations", 13.

158 Bastick, Grimm, and Kunz, Sexual Violence in Armed Conflict: Global Overview and Implications for the Security Sector.

159 Ibid., 172

160 Puechguirbal, "Gender Training for Peacekeepers: Lessons from the DRC", 120.
} 
the UN. I aim to analyse what the discursive practices of 'gender-awareness' are and how they relate to violence and security - hence shaping a Foucauldian notion of truth (knowledge) about gendered relations in (violent) armed conflict in peace and security.

I will first undertake a descriptive reading of the training package to establish what the material is aimed at accomplishing, and how it presents itself in its approach to gender and training (with also a focus on violence and security). Secondly, I will proceed to an analytic reading that seeks to unravel the meanings of statements, through the three nodal points that I have presented and explained. Through this double reading I will explore the discourse that emerges from the UN gendertraining concept.

\section{Descriptive reading (presentation of the material)}

In the descriptive reading, I intend to illustrate how the material presents itself. This is important to contrast the UN's statements on what the training material aims to do (and how 'it' sees itself) with how 'gender-awareness' is constructed as a discourse. From this, I will conclude that the gender-training material (and its related gender-awareness discourse) has emerged out of the UN's will to enhance its human rights standards in peace operations. Furthermore, the material presents itself as being a comprehensive 'tool' on gender and security, allowing peacekeepers to fully grasp how gender is socially constructed and how gender impacts on armed conflict, and to develop skills as to how their actions further affect gendered relations.

The training manual is founded on the United Nations human rights standards, specifically from the preamble of the UN charter ("we the peoples of the United Nations determined to reaffirm faith in fundamental human rights, in the dignity and worth of the human person, in the equal rights of men and women and of nations large and small..."), ${ }^{161}$ to the Universal Declaration of Human Rights (1948)

161 United Nations Department of Peacekeeping Operations, Gender and Peacekeeping Operations in-Mission Training. Introduction, iv. 
and other human rights treaties, and finally to other conventions and resolutions, including the Convention on the Elimination of All Forms of Discrimination against Women, the Beijing Declaration and Platform for Action (1995), the Windhoek Declaration (2000) and the Security Council Resolution 1325 (2000). What is common to these treaties, conventions and resolutions is their call for more equality between women and men, based on the principle of human rights. The discourse of 'gender equality' has been constant in all UN efforts to mainstream gender in its peace and security activities.

Following from these treaties and resolutions, the UN has stressed the importance of peacekeepers respecting the standards they have put in place.. ${ }^{162}$ Hence the training package is justified because it is important that the peacekeepers "reflect and practice the principles for which the United Nations stands". ${ }^{163}$ This is a crucial aspect to understanding how the discourse of 'gender-awareness' has been constructed, as will be explained further below.

The manual is intended to enable trainers to "prepare and deliver basic training on the meaning and implications of Gender and Peacekeeping Operations". ${ }^{164}$ The toolkit is presented in a concrete, simplistic and practical form to allow for easy manipulation by the instructors. It is composed of several exercises and practical situations in which peacekeepers can easily recognise their daily routine. These situations are intended to get peacekeepers to constantly test their understandings of the concepts and their progress. ${ }^{165}$ The manual put at the disposal of the trainers includes 'trainer text notes', 'presentation slides', 'readings', 'participants handouts for class activities' and 'additional materials., ${ }^{166}$ The training toolkit is designed to be completed in one day, or two half-days, which could be considered quite ambitious and too short to allow peacekeepers to assimilate all the notions.

\footnotetext{
162 Ibid., Introduction, iii - The UN refers to the numerous accusation against male soldiers exploiting and abusing local women during peace operations.

163 Ibid., Introduction, iii.

164 Ibid., Introduction, iii.

165 Ibid., Introduction, iii.

166 Ibid., Introduction, vi.
} 
The training toolkit stresses that the trainers should consider the participants' cultural differences in their teaching. Culture in the training package is defined as the "shared values, norms, traditions, customs, arts, history, folklore and institutions of a group of people". Further, "these shared beliefs serve as guides and determinants for behaviour within cultural groups". ${ }^{167}$ As Mackay (the creator of the DPKO training) argues: "[f]or pre-deployment training the material should be broad and generic, incorporating a wealth of different examples. For in-mission training, it will be important to contextualise and offer local examples whose relevance the peacekeeper will immediately be able to test”. ${ }^{168}$ Mackay highlights the fact that cultural factors were taken into account in the creation of the in-mission training, and that discussing cultural differences is essential in order to allow peacekeepers to understand how gender relations are socially constructed. ${ }^{169}$ The material also points out that language is an important issue, as it is sometimes very difficult to translate gender to the mother tongue of the participants and to differentiate it from 'sex.'

As the course overview of the training material states, the objectives of the course are "to show the relationships between men and women and [how] their gender roles and responsibilities are changed by violent conflict; to develop the skills to recognize the different needs, capacities and expectations of women and men in the host population; to make peacekeepers aware of the gender implications of their actions" $^{171}$ In other words, gender training is depicted as dealing with the way (violent) armed conflict affects both men and women, so that peacekeepers will be more aware of the impact of their actions.

However, it is important to note that, at this stage of the programme, the expected learning outcomes are much less ambitious than the previously mentioned

\footnotetext{
167 Ibid., Introduction, vii.

168 Lyytikäinen, "Gender Training for Peacekeepers: Preliminary Overview of United Nations

Peace Support Operations." Citing Angela Mackay, 11.

169 Ibid., 11.

170 United Nations Department of Peacekeeping Operations, Gender and Peacekeeping Operations in-Mission Training. Introduction, ix.

$171 \quad$ Ibid. Course Overview, xii.
} 
objectives of the course. Indeed, participants are expected to be more aware of 'why and how gender is relevant', 'how the human rights standards provide a basis for using a gender perspective', and 'the impact of their actions' on the community. This is the first irregularity that can be noted in the UN discourse, between what the objectives are and what is expected from peacekeepers. Regularities and irregularities contribute to creating a discourse of 'gender-awareness' (what to be aware of) as it will be further explained.

\section{Analytical reading}

I now intend to explore further how the UN constructs a notion of 'genderawareness' in its training packages for peacekeepers, through analytical reading of three discursive elements (or nodal points): [1] 'how the relations between women and men are structured (gender)', [2] 'how [gender is] affected by violent conflict (gender and violence)', and [3] 'how the mere presence of peacekeepers further impacts on [gendered] relations (gender and security)'. I aim to deconstruct the UN discourse surrounding 'gender-awareness' training; what does it mean for the UN and what does it imply for a critical concept of gender in peace? How, then, is 'gender-awareness' constructed as a discourse in the UN gender training toolkit? I will show how these three discursive elements are parts of the 'gender-awareness' training discursive formation and how this discursive formation is productive of a discourse of gender, violence and security.

\section{1- 'How the relations between women and men are structured' (gender)}

I first undertake to analyse how the UN training material talks about the way the relations between men and women are structured. In other words, how does the UN construct what to be aware of regarding the way gendered relations are structured? I will demonstrate that there are numerous irregularities in the way the UN addresses the concept of gender. While the apparent discourse is that gender is about 'gender' as a socially constructed variable, which looks at the relations between both men and women, the underlying rhetoric is that gender equates to women and sex. The latter is constructed as being the truth (in a Foucauldian 
fashion).

There is a significant lack of critical gender content in the training material, and this is because the UN's rhetoric on gender as a concept is often associated with facts and numbers that relate to "women's issues". The training material says "gender is often classified as 'women's issues'. This is wrong." Later, it says "the reason that much of the discussion [in the training material] focuses on women's interests, the effects of conflict on women and their exclusion from the peace-building process etc. should become self-evident". The contradiction (or irregularity) in these statements is quite striking. Indeed, with the second statement, the UN does not appear to tackle how this discussion should be about the construction of gender (and of things as constituting 'women's issues'). As a result, gender continues to be introduced both as being about 'women' and as being a 'personal issue', and there is no reference to the way gender (with notions of feminities and masculinities) is constructed.

Further, the training toolkit represents gender as something that is 'personal', removing gender from the political field. Introducing the material, the UN DPKO presents gender as quite a challenging subject because it is 'contentious', 'emotional' and 'political'. The UN stresses that "some personnel may find that discussing how culturally defined roles and responsibilities for women and men differ among regions and communities can be unsettling or even confrontational". ${ }^{172}$ Gender is presented as being a confrontational subject for three main reasons: gender is 'contentious' as confusions between sex and gender can arise among participants; gender is 'emotional' because "it strikes at the heart of who we are or think we are as individuals"; and gender is 'political' because it is challenging the status quo of all social institutions (family and state) so it is likely to unleash resistance. ${ }^{173}$ The challenge is therefore to bring up gender issues "in a non-confrontational as well as

\footnotetext{
172 Lyytikäinen, "Gender Training for Peacekeepers: Preliminary Overview of United Nations Peace Support Operations", 15, citing United Nations 2004: 46.

173 United Nations Department of Peacekeeping Operations, Gender and Peacekeeping Operations in-Mission Training. Introduction, viii.
} 
practice-oriented way". ${ }^{174}$ I argue, however, that the way the UN presents gender as a 'challenging topic' is questionable and contributes to the construction of gender as a personal issue. The UN presents gender as personal because it implies that participants (individuals) [1] will struggle with the conceptual notions of sex and gender (contentious), [2] will have their deepest-seated beliefs touched (emotional), and [3] will resist meanings challenging normative social structures (political).

This is another irregularity in the discourse: while the UN affirms that gender is a political subject, the underlying discourse is that gender is a personal subject. Firstly, gender is not a challenging topic because confusions arise between sex and gender; rather it is a challenging topic because it unravels how gender has been constructed as equating to sex. Secondly, the UN is offering a notion of gender that would be 'emotional'. Teaching and learning about gender could raise emotions in the classroom; however, it could also bring humour, interest, enlightenment, strength, etc. Reducing gender to the realm of emotionality is problematic as it does not question the underlying assumption about why and how gender has been constructed as an emotional/women's issue, rather than as a conceptual subject. Thirdly, it is not because participants will resist the new concept that makes gender a political concept; rather gender is political because it questions the discursive link between power and men (and how hegemonic masculinities have been shaped) and it is political because gender is about the "big picture" of international relations. ${ }^{175}$ Indeed, as I have previously highlighted in the literature review, the creation of masculinities as a dominant discourse (or discursive norm) in the military institution makes it extremely difficult to challenge.

Further, while gender is presented and discussed in the training kit as being different to sex, when the discourse is analysed gender remains constructed as a 'women's issue'. This contributes to the formation of a double discourse, one

\footnotetext{
$174 \quad$ Lyytikäinen, "Gender Training for Peacekeepers: Preliminary Overview of United Nations Peace Support Operations", 15.

175 Cockburn, From Where We Stand: War, Women's Activism and Feminist Analysis. Citing Cynthia Enloe, 231.
} 
explicit, which is 'gender is different from sex as it is socially constructed' (the UN's statement), another more implicit, which is 'gender still equates to women's issues'. The way relations between women and men are constructed and do not depend on physiological attributes is vaguely touched on in the training tool, but I could not find evidence that the notion was critically addressed. For example, training sessions do not critically assess the way that gender stereotypes might be (re)produced. Indeed, the UN treats gender in a rather superficial way. The first exercise, 'What Is Gender About?', does not emphasise in any way that gender roles are constructed. For example, the material refers to gender as "describ[ing] the social roles and relations between men and women in society", as "affect[ing] all aspects of life - economic, political and social", and as "show[ing] what we expect men and women to do and how we expect them to behave" ${ }^{176}$ Not pointing out that such relations are not natural but are in fact constructed is running the risk that participants will confuse gender and sex even further.

The other implicit discourse becomes apparent when one looks at how statements appear in the UN gender-training discourse, and this involves looking both at the regularity and dispersion of statements. I have chosen to analyse (PowerPoint) images from the section 'Gender and Sex', which is particularly relevant to examining how the UN discourse is constructed around those notions. I have chosen two illustrations: the first one is entitled 'Gender and Sex' (slide 26) and the second one 'Gender roles' (slide 28). The 'Gender and Sex' slide is composed of two images: one representing a woman in a typical 1950s' domestic scene, she is cooking and taking care of her two children. The second image, slightly larger, is juxtaposed next to the first image, and shows men (in Switzerland) voting publicly. There is not much information about these pictures, apart from the fact that they are supposed to "allow for the transition to 'Gender roles"”. 177 Indeed the 'Gender roles' slide, made up of two other images, depicts how gender roles can change. The first one illustrates a military woman accompanied by two male soldiers. They are all looking in the same direction, which one can assume is toward the commander. To the right

\footnotetext{
176 United Nations Department of Peacekeeping Operations, Gender and Peacekeeping Operations in-Mission Training. 'A Gender Perspective'- Text 3.

177 Ibid., "A Gender Perspective" - Text 18.
} 
of this picture, a man is carrying and kissing a baby. He has a red cross on his arm. All these pictures contain plenty of symbols that are easily noticeable: the first pictorial duo represents traditional gender stereotypes, i.e. child rearing and cooking for women, and assuming a public and political function (voting) for men. The second set of images clearly indicates how (gender) roles can be inverted.

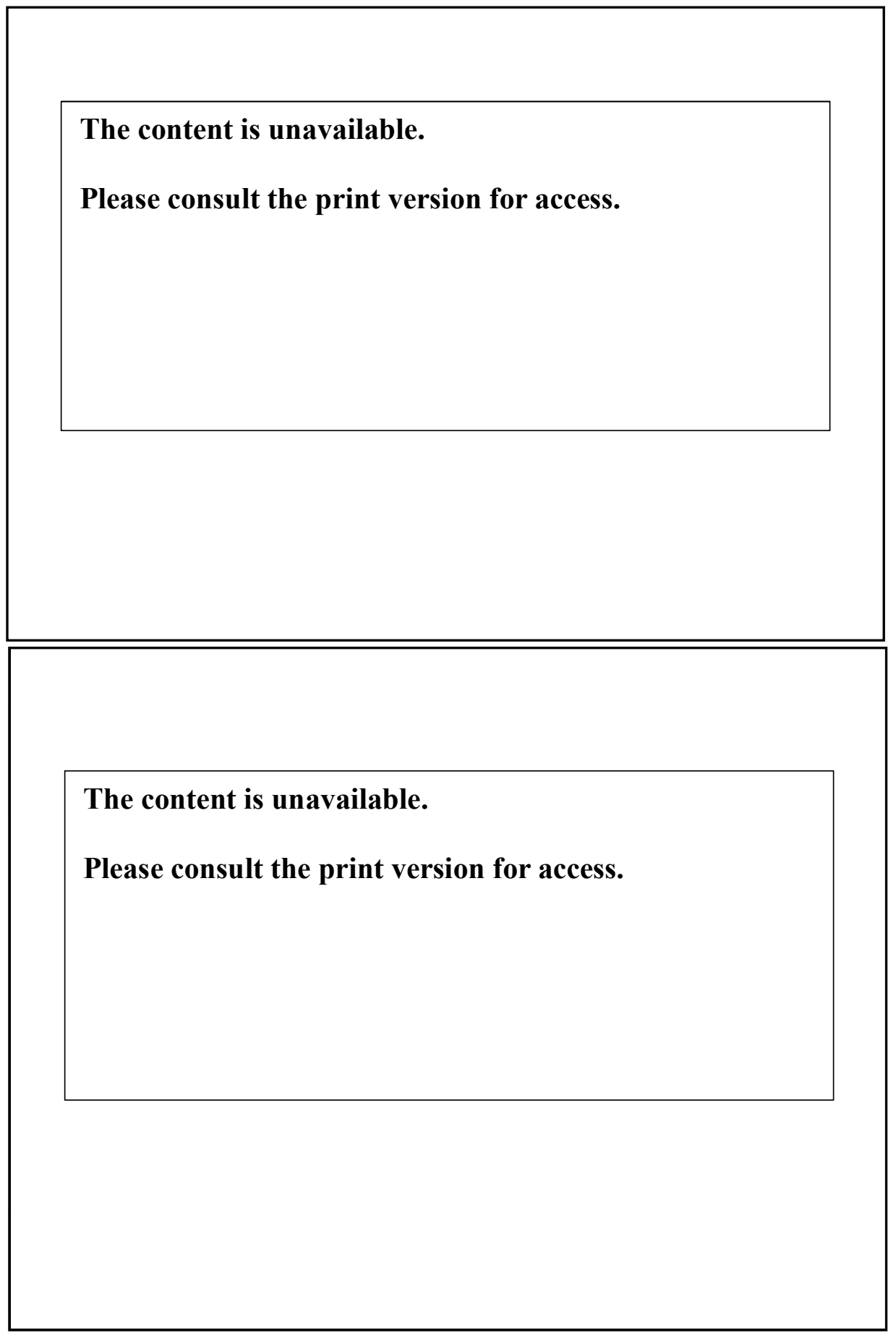

The second set of images is even more problematic. While the images are supposed to show how gender roles can be inverted, they offer another message, which further 
excludes women from the political realm and reinforces the masculine identity of peacekeepers. The first image showing a woman joining the military, between two men soldiers, could be (re)producing a discourse of 'what normality is' - it is not normal to see a woman wearing a military jacket, assuming political (and masculine) functions. It would be important for the trainer to discuss this aspect and whether the woman is perceived as 'abnormal' by the participants and why. Secondly, the image showing a man cuddling a baby in quite an affectionate manner contributes to (re)producing a discourse on what a good peacekeeper should be, that is taking care of and 'protecting' the community - hence, still exercising a public role and having a heroic identity (by protecting the most vulnerable). The discursive practices are shaping subjects (as women or men), and what their 'normal' and expected behaviour should be - forming a Foucauldian notion of (normalised) truth in the notions of feminities and masculinities and their appropriate behaviours.

Across these few examples, the discursive practices in the UN training material appear to construct gender as being synonymous with sex and women, hence shaping 'gender-awareness' as being 'sex and women awareness'. Further, gender is presented as an a-political subject or a personal topic. As gender is both associated with sex/women and the personal, this contributes to further (re)producing a representation of women as excluded from the field of politics. It constructs 'gender-awareness' as an empty signifier: it does not really mean awareness on gender, it means awareness on sex and women.

\section{2- 'How [gender is] affected by violent conflict' (gender and violence)}

I now examine how the UN constructs gender in relation to violence, and I look at the discursive practices on gendered roles and responsibilities in armed conflict. The research will show that the way 'gender-based violence' is constructed contributes to further position women as a 'victim' subject and men as a 'protector/heroic' subject. I will demonstrate that the contradictory identities of peacekeepers are rendered silent in the UN discourse, which does not allow any room for the deconstruction of militarised masculinities in gender training. Deconstructing militarised masculinities and reconstructing a new identity that 
embodies both feminine and masculine is essential to bringing real change in the way peace operations are undertaken.

First, the UN discourse on the gendered roles and responsibilities in violent conflict in the training material contributes to (re)producing women as 'victims'. This is mostly done through what I call the 'who question'. Indeed, addressing genderbased violence through the 'who question' contributes to producing quantifiable data about 'who' suffers the most and 'who' suffers about 'what'. Indeed, gender and violence are mostly associated with facts and figures. In the 'true and false' introductory exercise 'What Gender Is About', gender is addressed in a quantitative, factual, manner: "50 per cent of all displaced are women and children”, "more women and children than men are killed or injured by anti-personal landmines", etc. ${ }^{178}$ Similarly, the PowerPoint presentation presents 'gender analysis' as a concept that shows us "who is vulnerable and most likely to suffer", or "who needs protection". ${ }^{179}$

Hence the UN DPKO is constructing a notion of gender and violence that is factual, concerns number and usually addresses the question of "who suffers the most?". It suggests that women are the ones 'who' are most likely to suffer and need protection. This reminds us of the preamble of UNSCR 1325 that immediately positions women (and children) as "the vast majority of those adversely affected by armed conflict". ${ }^{181}$ It is not helpful to think about gendered violence in terms of "point-scoring over whether women or men suffer the most". ${ }^{182}$ I draw here on Shepherd's argument that it is counterproductive to classify 'women' or 'men' in terms of who suffers the most (furthermore, the statistics to back these assertions are usually based on quantitative (number-values) research, not qualitative

\footnotetext{
178 Ibid., "A Gendered Perspective - Text”, 6.

179 Ibid., "A Gendered Perspective - Slides", 46.

180 The gender material that invites us to think about "Why women and children are more vulnerable [to landmine]" is another example. Ibid., "A Gendered Perspective - Text", 8. There are many other examples that cannot all be addressed within the scope of this project.

181 Shepherd, Gender, Violence and Security: Discourse as Practice, 115.

182 Ibid., 116.
} 
research, so their relevance must be questioned). ${ }^{183}$

Furthermore, through the 'who question', women are often associated with children. This contributes to (re)producing the 'woman and children' 'fixings' that have been previously highlighted in the discourse of the UN (UNSCR 1325 in particular). Shepherd stresses that "one of the main problems in associating women and children in international relations is that it feeds the nationalist discourse that defines women mainly as the cultural bearers of society". ${ }^{184}$ Associating women with children reinforces the fact that women are mothers and nurturers, and that men must protect 'their' women and children. ${ }^{185}$ It contributes to producing a discourse that essentialises women as vulnerable creatures. Shepherd argues that "women are part of 'women and children', 'are targeted by combatants' and [are] therefore implicitly not combatants, women have 'special needs' and require 'protection' (UNSC 2oooa: preamble), particularly from 'gender-based violence... rape and other forms of sexual abuse (Article 10). Overall women are 'linked by their gender through their vulnerability to violence' in this representation (Bahdi 2003: 46) and therefore fixed as vulnerable." ${ }^{186}$ This is problematic when training about gender, because it suggests that peacekeepers should be trained for the 'specific needs' of women whereas these issues should concern everyone. It should also incorporate a discussion on why women are perceived this way (through which cultural and social construct lenses?). It contributes to producing a discourse of gender and violence as being 'sexual-based violence'.

Further, as gendered violence is constructed as being sexual-based violence, it produces a discourse of gender-awareness training as 'sexual-based-violence awareness training'. When addressing what 'gender-based violence' is, the UN training tool mentions that it concerns "sexual violence against women and girls; women exposed to sexual mutilation, pregnancies, STDs and consequent

\footnotetext{
183 Ibid., 116.

184 Ibid., 119, quoting Puechguirbal, 2004, 11.

185 Ibid.

186 Ibid., 119.
} 
community rejection and inability to marry; [and that women are] particularly vulnerable in refugee/IDP camps”. ${ }^{187}$ Through its discourse, the training material focuses both on 'women' as the ones concerned about gender-based violence and on the sexual forms of violence. While it is also mentioned that "men also suffer sexual abuse in conflict situations", the reference to men is quite succinct, usually anecdotal and not explicit as to the different forms of gender-based violence that men suffer from. ${ }^{188}$ It refers to 'sexual abuse', namely the rape of men, which is taboo in the UN discourse and the discourse of war, peace and security in general. This is one of the rare references to the fact that men too are victims of gender and sexual violence in conflict.

As I will explain further in the third part of the analysis, the UN discourse on gender and violence in its training material subverts its primary function, which is to train peacekeepers to be aware of gender issues: it is in fact training peacekeepers to be aware of the sexual abuses that women go through in violent conflict. While it is certainly a very crucial and important issue that needs to be addressed by the UN peace operations, other gender issues are not addressed, or even raised, which is problematic. It reinforces the discourse of dominant masculinities as being the only discourse that takes place in the peace and security realm.

Thus, violence is used to produce and reproduce (Foucauldian) 'gender' categories, while it should be addressed regarding gender as "lived identity - something that affects both 'men' and 'women"'. 189 Indeed, the many agencies of women are rendered silent in the UN discourse. As it has been discussed earlier, women's agency in war is embedded in the tension between 'victims' and 'active participants',

\footnotetext{
187 United Nations Department of Peacekeeping Operations, Gender and Peacekeeping Operations in-Mission Training. "A Gendered Perspective - Slides", 49. The training material also points out that "gender-based violence is a form of discrimination that seriously inhibits women's ability to enjoy rights and freedoms on a basis of equality with men". "A Gendered Perspective - Text", 25 (emphasis added). 188 The training tool does mention men's rape, for example, pointing out that very little research has been done on the topic. It says that "anecdotal evidence exists of regular sexual threats and violence against men and boys by members of the RUF in Sierra Leone. The RUF referred to their male victims as 'women"'. Ibid. "A Gendered Perspective - Text", 26 (emphasis added). Thus, the UN is treating rape, and men's gendered-based violence as something anecdotal.

189 Shepherd, Gender, Violence and Security: Discourse as Practice, 116.
} 
in which they don't always have a choice. ${ }^{190}$ Haleh Afshar argues that "conflicts can both empower and disempower women, since women can be at the same time included in practice and yet excluded ideologically, or they may be both victims and agents of change". ${ }^{191}$ Understanding women's dual subjectivities in conflict is particularly important to (re)conceptualising a notion of gendered violence which is a 'lived identity', i.e. something that can move from one box to another, instead of being rigidly fixed and categorised.

Men, on the other hand, are subjected to discourse about their identity which is associated with militarised values. But, at the same time, they are asked to deny those values, to adopt another form of masculinity, one which is related to the 'breadwinner/protector' masculine function. The UN discourse in the training material contributes to removing masculine subjectivity associated with aggressiveness and tries to reconstruct another image of the 'hero'; someone who cares for and protects the community. Peacekeepers are depicted as 'good', 'nice', smiling and helpful figures, qualities that are seen to be essential elements for the mission of the peacekeeper and the creation of a long-lasting peace. As illustrated on the PowerPoint presentation, peacekeeping operations "save lives, human rights, restore conditions for peace and security, enhance the population's ability to deal with crisis and restore society". ${ }^{192}$ Thus, the discourse surrounding peacekeeping operations is that it contributes to 'saving', 'protecting', 'restoring', and 'enhancing'; terms that are all positive and belong to the vocabulary of heroism. Heroism, however, is not constructed as being a gendered quality. On the contrary, heroism (and qualities that are associated with it, such as bravery, obedience and courage) is constructed as being a 'masculine quality', i.e. a quality that only men possess. When analysing the image accompanying the UN discourse on what peacekeeping missions are, one can see a (Canadian) male peacekeeper (wearing a blue beret which suggests his connection to military peacekeeping) talking and smiling with a

\footnotetext{
190 Haleh Afshar, ed. Introduction War and Peace: What Do Women Contribute? Development, Women, and War: Feminist Perspectives (Oxford: Oxfam GB,2004), 3.

191 Ibid., 2.

192 United Nations Department of Peacekeeping Operations, Gender and Peacekeeping Operations in-Mission Training. "A Gendered Perspective - Slides", 46.
} 
woman in quite a relaxed posture. The woman is smiling as well and is carrying a child. Another child is behind her, looking at the scene. The peacekeeper is bending towards the woman, suggesting a protective attitude. The scene depicts the helpingand-caring image of a soldier, who is helping-and-caring-for-woman-and-children. Thus, while this discourse is deconstructing the 'manly', aggressive soldier masculinity to propose a more 'peaceful' one, it is at the same time (re)producing a traditional image of masculinity: breadwinner, protector of woman and children.

\section{The content is unavailable.}

Please consult the print version for access.

Masculinity in peacekeeping is composed of two conflicting identities: the militarised, violent masculinity (that I call manly-aggressive-ness) and the protector of the vulnerable (heroic-protection-ness) masculinity. As Sandra Whitworth stresses: "lying at the very core of peacekeeping is a contradiction: on the one hand, it depends on the individuals (mostly men) who have been constructed as soldiers, and on the other hand, it demands that they deny many of the traits they have come to understand being a soldier entails". ${ }^{193}$ At the core of peace operations, soldiers are being described in terms of what a good soldier should be (i.e. engaging with a certain notion of militarised masculinity) and are asked at the same time to remove those fundamental traits in order to adopt new 
ones that are more adequate to the work of peacekeepers. This entails, for example, removing weapons for self-defence. Whitworth points out that this double discourse provokes a 'crisis of masculinities' (or an “ideology of manliness” for Enloe) ${ }^{194}$ : "in this way, often ridiculed and demeaned within traditional military culture, the resolution of the military's legitimating crisis becomes to some extent a crisis of masculinity. All the messages a soldier receives about appropriately masculine behavior are fundamentally at odds with what is expected in a peace operation"," 195

Thus, there is a strong contradiction in peacekeeping between the image of the nice, kind soldier helping the community, which is delivered by certain countries (e.g. Canada and Denmark), and the more robust-violent common image of the soldier. $^{196}$

This contradiction becomes quite problematic when training for gender-awareness and discussing masculinities, as it potentially seeks to remove men from their (constructed militarised and heroic) hegemonic masculine identities. ${ }^{197}$ Once we explain to men that they cannot be as they have been told a good soldier should be, that being a soldier entails both traits of 'manly-aggressive-ness' and 'heroicprotection-ness', they might feel that they no longer have a solid identity. Puechguirbal proposes that we adopt a new concept of masculinities in gender training, which focuses on "patterns of masculinity more open to negotiation, cooperation and equality". ${ }^{198}$ She goes on to show that "peacekeepers are asked to lead a mission for peace, not to fight. [...]. This approach requires skills that are definitively people-oriented". 99 Thus the concept of hegemonic masculinities should be deconstructed in training sessions to bring about a new one, a masculinity that is more adequate and relevant to the function of peacekeepers and that has the

\footnotetext{
194 Ibid., 16. The ideology of manliness entails characteristics such as violence, discipline, homophobia, misogyny and racism.

195 Ibid., 16.

196 Ibid., 16.

197 Puechguirbal, "Gender Training for Peacekeepers: Lessons from the DRC", 124.

198 Ibid., 124, citing R.W. Connell.

199 Ibid., 124.
} 
potential to remove masculine identities based on the dichotomy of 'strong-andwarrior' males and 'weak-but-peaceful' females. To do that, I argue that the new concept of masculinity that needs to be addressed in gender-training modules for peacekeepers should include characteristics of both masculinity and femininity, to be able to fully bring about new ways of thinking about the transformation of gender roles.

Thus, when analysing the discursive practices that concern how violent conflict impacts on gender, one can see that women are represented as 'victims' while men are represented as 'heroes'. While this is not a new idea, what this analysis shows is that such discourses are reproduced from the UN policies (UNSCR 1325) to the UN implementation of gender 'tools'. Further, I have identified that 'gender-awareness' is actually used to both deconstruct the aggressive identity of (male) soldiers and construct the heroic-protecting identity of (male) peacekeepers. 'Genderawareness' here acts as a (Foucauldian) disciplinary technology that tells (male) peacekeepers how to behave with women and children. ${ }^{200}$ While it seeks to deconstruct one aspect of a soldier's identity, it doesn't, however, remove hegemonic masculinities.

\section{3- 'How the mere presence of peacekeepers further impacts on [gendered] relations' (gender, violence and security)}

I now analyse how the relations between peacekeeping and gender issues appear in the UN discourse, which will potentially contribute to creating a (Foucauldian) knowledge about the discourse of gender, violence and security. I will interrogate what the UN DPKO means by 'bringing (gender-awareness) skills' to peacekeepers and how it produces male peacekeepers as agents of knowledge. Indeed, the main objectives of the training course are "to develop the skills to recognize the different needs, capacities and expectations of women and men in the host population [and] to make peacekeepers aware of the gender implications of their actions”. ${ }^{201}$

\footnotetext{
$200 \quad$ Foucault, Discipline and Punish: The Birth of the Prison. 1977.

201 United Nations Department of Peacekeeping Operations, Gender and Peacekeeping Operations in-Mission Training. Course overview, xii.
} 
This research will show that the UN has not fully recognised the potential created by what a critical understanding of gender awareness could bring to gender and security. Indeed, this analysis will demonstrate that [1] the 'basic skills' are not clearly identified and are mostly associated with a 'human-rights-based' approach and UN standards (or codes of conduct) to be respected, ${ }^{202}$ and [2] the cultural context in which gender and security are constructed has not been sufficiently integrated into the UN approach to training, which does not allow for a concept of gender that is translated into different cultural contexts. ${ }^{203}$

UN peacekeeping missions affect gender inequalities; hence it is essential that peacekeepers integrate a gender-sensitive approach into all their activities. Puechguirbal explains that "participants [...] need to understand the impact of their own presence in the community, and the effects of the imbalance of resources and power between them and the local population”. ${ }^{204}$ Local women see peacekeepers as resourceful and powerful and are more easily tempted to seek help in situations when they are economically weak. However, while feeling good about the help they provide, peacekeepers do not consider the consequences of their actions, which leads to further increases in gender imbalances, especially when they leave the country. $^{205}$

The UN highlights the fact that gender training is "not a luxury, but a requirement for improving the effective discharge of the mission's mandate and reducing both harmful forms of behaviour by peacekeeping personnel and unintended negative

\footnotetext{
202 Note here that while it would be interesting to analyse how the UN discourse on human rights is translated in its training material, this would go beyond the scope of this research. Furthermore, the UN mentions the debate between cultural relativism and universalism, which cannot be addressed in this paper either. This paper focuses on how gender is constructed, and this involves looking at how the UN constructs the 'human rights' discourse through a gender lens.

203 Similarly, much more would need to be researched and analysed on the way the UN has addressed culture and gender. This paper points out the need for more (discursive) space to be devoted to the cultural context in which gender is applied, and I argue that gender in gender training needs to be translated depending on the cultural context in which it is evaluated.

204 Puechguirbal, "Gender Training for Peacekeepers: Lessons from the DRC", 120.

205 Ibid., 120.
} 
effects of mission policies and programmes”. ${ }^{206}$ Focusing gender training on the "harmful forms of behaviour", e.g. the sexual abuses on women by peacekeepers, is quite problematic and even though it needs to be tackled, it does not fully engage with a notion of 'gender-awareness' at all levels. ${ }^{207}$ It is, again, reducing the UN's level of discourse to 'women's issues'. Of course, it is very important to address issues of sexual abuses, and the fact that the UN seeks to reduce and even eliminate sexual exploitation is crucial and encouraging. What is problematic, however, is that it constructs a discourse on gender, violence and security that is limiting.

First, the UN discourse on 'gender-awareness' is based on a human (as women) rights-based approach, limiting its scope. This discourse contributes to reducing the concept of 'gender-awareness' to a 'code of conduct', i.e. to behavioural rules that should be adopted by (male) peacekeepers (the subjects). The training material explains that at the end of the course, the participants are expected to "understand how human rights standards provide a basis for using a gender perspective”. ${ }^{208} \mathrm{With}$ respect to this expected learning outcome, the material provides basic training in the UN concept of Human Rights and the Convention on the Elimination of Discrimination against Women. The latter is explained as dealing "specifically with [the protection of] women's rights". ${ }^{209}$ The promotion of women's human rights has been a major issue over the past 10 to 20 years, as it recognises that the human rights norms are gender neutral, preventing those standards from applying to everyone. ${ }^{210}$ This aspect is emphasised particularly in the UN discourse, which stresses that the course will focus on 'non-discrimination' (against women) and 'gender-based violence' (which I have already shown can be reduced to 'sexual (women)-based violence'). $^{211}$

\footnotetext{
206 Lyytikäinen, "Gender Training for Peacekeepers: Preliminary Overview of United Nations Peace Support Operations", 7, citing UN DPKO 2004: 45.

207 See also how the UNSCR 1325 contextualises gender training in peacekeeping. The resolution seeks to encourage states to develop such training in their pre-deployment and in-mission operations, using as an argument the preventive impact that it could have on sexual exploitation and abuses.

208 United Nations Department of Peacekeeping Operations, Gender and Peacekeeping Operations in-Mission Training. "A Gendered Perspective - Slides", 37.

$209 \quad$ Ibid., "A Gendered Perspective - Slides", 32-39.

210 Ibid., "A Gendered Perspective - Text", 21-22.

211 Ibid., A Gendered Perspective - Text", 22.
} 
Hence the UN is constructing a discourse of gender awareness that is 'standards of women's rights'. The UN intends to implement a code of conduct that would prevent (male) peacekeepers from acting against women's human rights. In an exercise entitled 'The Collaborator', peacekeepers are invited to think about their 'mandate' and what it implies in terms of women's rights. A case study describes a woman asking peacekeepers for help because she has been raped by enemy troops and fears being killed by her husband. The case study asks participants to think about what they should do if helping this woman is not covered by their mandate. This exercise is aimed at bringing 'gender-awareness' skills to peacekeepers. However, what this exercise is really doing is installing new (discursive) norms of behaviours that peacekeepers should adopt, which is to integrate a 'women's rights' perspective into their work. Puechguirbal argues that teaching a gendered code of conduct should not be reduced to a listing of rules to respect. Peacekeepers need to understand the impact of the context of conflict on girls and women, but also on boys and men. ${ }^{212}$ By focusing on 'women's rights' as synonymous with 'gender-awareness', the UN does not provide peacekeepers with a real understanding of gender issues that would help them to have a comprehensive approach to gender in peace and security, and a full impact on gender imbalances. It also constructs a discourse of gendered security as being security-for-women.

The content is unavailable.

Please consult the print version for access.

212 It would be interesting to find out whether such training contributes, indeed, to eliminating forms of violence against women. 
By doing so, it is also implying that the target of this training package is 'men'. The UN discourse on 'gender-awareness' suggests that 'men' should be trained about 'women's human rights'. Male peacekeepers are formed to be the agents of knowledge for peace and security. There are few references or exercises designed for both sexes. Female peacekeepers are not included in the training material as agents for peace and security. Once again, women's subjectivities are produced as being the victims that 'men' peacekeepers should protect. This discourse contributes to further excluding men from the realm of gender, which is constructed as something woman-related, and therefore weak, abstract and, in a Foucauldian sense, abnormal. It legitimates the fact that male peacekeepers need training on something that they do not fully understand and that is abnormal to them. It also contributes to further excluding women from the realm of peace, as they are categorised as victims and not agents of peace. Thus, this analysis has shown that 'gender-awareness' training is used as a disciplinary technology, whose discourse constructs women as a 'deviant, particular' subjects to be studied by men (male peacekeepers as agents of knowledge).

While men need training about 'women's rights', women, on the other hand, need training about 'peace' (peace here refers to the 'UN peace operations' - something political; it does not refer to peace as being the idea of the 'motherly-pacifist', a quality which has been attributed to women due to their sex). The UNSC Reports (2002 and 2004) suggest that women need training to be involved in peace activities.

Hence what is suggested is that female peacekeepers need training to contribute to peace reconstruction and that male peacekeepers need training to deal with women's issues. Women are again represented as an anomaly. Shepherd suggests that "in representing women as needing 'support', 'training' and 'skills building', the Reports construct women as a problem to be overcome, as opposed to problematizing the complexity of gender. [...] the Reports fail to mention that many men need similar interventions on their behalf as they are marginalized on account 
of their class, race, politics, sexuality and so on." ${ }^{213}$ By distinguishing 'who' needs 'what' based on sex attributes, the gender-awareness (discipline) technology further (re)produces the dichotomy between women and men, and almost produces a discourse which suggests that women need to be trained for the political realm while men need to be trained for the private realm.

Furthermore, the UN gender-awareness discourse does not fully acknowledge the cultural context in which masculinities and feminities are constructed. Indeed, awareness of gender is understood in a Western-liberal way and is not mission specific. It is entirely the trainer's responsibility to "add mission-specific, contextspecific examples". 214 Trainers are expected to customise and adapt the training material to the context of the mission and the culture of the audience. The UN stresses the importance of including local populations as participants if possible. Local representatives were included as a resource during the DPKO Gender and Peacekeeping In-Mission training in Ethiopia, Sierra Leone and DRC and the UN commented that it was a real success: "the 'peacekept' were able to provide context and translate 'gender' in that society for the peacekeepers". ${ }^{215}$ The in-mission training package must include elements of cultural context. Puechguirbal explains that "the importance of context-specific training is evident". She takes as an example the mission in DRC (MONUC), in which legal consent for sexual relations is 14, but peacekeepers are bound by the international law of consent, which is $18 .^{216}$

While acknowledging the importance of 'doing' cultural gender, which represents how the material presents itself, I suggest that the UN discourse does not allow for a comprehensive approach to culture and gender in security. 'Gender-awareness' is

\footnotetext{
213 Shepherd, Gender, Violence and Security: Discourse as Practice, 92.

$214 \quad$ United Nations Department of Peacekeeping Operations, Gender and Peacekeeping Operations in-Mission Training. 'A Gender Perspective'-Text 2.

215 Lyytikäinen, "Gender Training for Peacekeepers: Preliminary Overview of United Nations Peace Support Operations", 11. The UN comment about the 'real success' of including local representatives (and how local participants were used) should be subjected to further research. From a discourse analysis perspective, it can only show 'how the training material (the UN) represents itself' but cannot be taken as evidence that gender is indeed translated into local contexts. I shall focus on how the in-mission training material constructs gender in relation to cultural context.

216 Puechguirbal, "Gender Training for Peacekeepers: Lessons from the DRC".
} 
constructed out of its cultural signification and further reproduces both the 'us' versus 'them' dichotomy, and the 'men' versus ‘women' one. In the exercise 'Reading the Signs', the peacekeepers are invited to think about their behaviour in public places. The exercise describes a 'European UN male military' that starts talking and then gesticulating over local women. Everyone seems to enjoy themselves; however, their behaviour is noticed by some of the waiters. ${ }^{217}$ The participants are invited to think about "how the peacekeepers are perceived by the community", "the economic power of foreigners", "the perceived 'political' power of authority figures in uniform", as well as "the racial distinctions". ${ }^{218}$ These are good questions that need to be addressed and shows that the UN has taken some important steps. However, looking more closely at the exercise, the material suggests that there is a single, acultural notion of masculinity and feminity. It provides a Western view on how masculinities and feminities are constructed.

While participants are asked to react regarding their own culture, the way the exercise is constructed implies that [1] 'masculinities' equate to uniform and power, [2] 'masculinities' are constructed in a uniform way. But it does not deconstruct the way masculinities are shaped in culture. Indeed, it is assumed that masculinities are all the same and do not depend on any cultural context. It assumes that masculinities equate to "authority figures in uniform" but does not acknowledge that this is what has been constructed as the dominant and hegemonic notion of masculinity in the Western/liberal/UN discourse. Furthermore, it does not interrogate any notion of feminities in a local context. The exercise presents various situations of the gender, race and nature of peacekeepers, but simply categorises 'local women' ("the rest", "the other") in the same box, without interrogating the local and cultural context of their feminities and how this impacts on their relations with the peacekeepers. In certain cultures, for example, women are prohibited from talking to male strangers. ${ }^{219}$ The exercise contributes to constructing a discourse of

\footnotetext{
217 United Nations Department of Peacekeeping Operations, Gender and Peacekeeping Operations in-Mission Training. 'A Gender Perspective'-Text 15-17. There are different versions provided with civilian/military/European/African/male/female.

218 Ibid., 'A Gender Perspective'-Text, 17.

219 Gerard J. DeGroot, "A Few Good Women: Gender Stereotypes, the Military and Peacekeeping," International Peacekeeping 8, no. 2 (2001).
} 
'gender-awareness' that is disassociated from its cultural content. It seeks to make peacekeepers aware of their perceived 'Westernised militarised and powerful' masculinity but does not deconstruct masculinities and feminities in relation to cultural contexts. It contributes to reproducing a gendered version of the 'West' versus the 'rest'.

Including local participants should be automatic in each training session, to avoid imposing a notion of gender that is Westernised and universalised. Indeed, speaking of the "other" has been vehemently criticised by post-colonialist writers, such as Said, who argues that a discourse of 'the rest' or 'the other' has been created along with a discourse of 'the West'. ${ }^{220}$ This discourse has been universalised as being the only possible truth, without allowing the possibility of the colonised countries expressing their own voice: "the cry of the victims of colonialism was ultimately the cry to be heard in another language”.221 In terms of gender training, analysing the UN discourse of 'gender-awareness' shows that it does not allow for a concept of gender that can be translated into a local context. ${ }^{222}$

By focusing on Western representations of relations between men and women, the UN discourse is somehow reducing the concept of gender and excluding 'other ways of doing gender' from its realm. This discourse is problematic in the context of peace operations, as it reaches and impacts on 'other' local cultures and should consider the formation of feminities and masculinities in 'other' cultures. It shows that the construction of masculinities as the dominant framework to conceptualise power and international security has been done through a Western (liberal) framework. Hence the way gender awareness has been constructed does not involve local and

220 Edward Said, Orientalism (New York: Vintage, 1979). The dichotomy between the West and the others has created a discourse on the Orient. Said explains that such discourse misrepresents what is the Orient. He argues that the West has created an image of the Orient constructed in opposition to its own subjectivity. This has engendered the creation of stereotypes and false perception of both the West and 'the others'.

221 Ashis Nandy, The Intimate Enemy: Loss and Recovery of Self under Colonialism (Delhi: Oxford University Press, 1983).

222 It would be interesting to further investigate gender through the lens of post-colonialism. Indeed, 'local' practices seem often unnatural to Western eyes, and much literature addresses the question of liberalism (including the UN) and how it imposes certain views and certain norms on those that have been categorised as 'the others'. 
cultural 'awareness' of gender issues (and the construction of local feminities and masculinities).

This framework produces gender training as a technology that carries a certain notion of truth as to masculinities and feminities - and hence is embedded in power. I will undertake now to explore further this notion.

\section{Gender-awareness training as a technology}

Through discourse analysis I have examined how the concept of 'gender-awareness' has been constructed in UN gender-training materials. I have shown that the way gender awareness is done does not take advantage of its full potential, that is, to allow for a new gendered approach in peace and security. The concept of 'genderawareness', indeed, should carry deeper political meanings. It implies going to the heart of the hegemonic masculinities, deconstructing them and building a new notion of masculinity that would be aware of how relations are gendered and would consider both masculinity and feminity. If done correctly, gender awareness could change the way peace and security is currently structured, challenging the dominant social structures, to finally reach gender balance.

Here I discuss 'gender-awareness training' as being further established as a technology that acts upon the individual to shape its bodies of knowledge. Discipline here is not used as 'punishment', but as a 'tool' that allows the development of a body of skills and knowledge. ${ }^{223}$ Foucault relates discipline as punishment and body of skills "through its concept of power-knowledge. He goes beyond the conventional view that the development and acquisition of knowledge necessarily makes people more powerful or is 'good for them'. Rather, knowledge is something that makes us its subjects because we make sense of ourselves by referring back to various bodies of knowledge". ${ }^{224}$ The meaning of "making sense of ourselves" here is very important. It explains how (male) peacekeepers can make sense of themselves by referring to the bodies of knowledge constructed by the UN

223 Danaher, Schirato and Webb, Understanding Foucault, 50.
224 Ibid., 50. 
gender-training material. However, it is not solely the training material that constructs and shapes (soldiers') subjectivities. Indeed, the training material is itself embedded in the dominant discourse surrounding the military field. I am not arguing that gender training alone would constitute the subjectivity of peacekeepers. Gender-awareness training as a technology is just a 'tool' that reinforces the already-existing discourse.

Thus, gender awareness as technology is embedded in three main discourses, related to gender, violence and security (and how they interrelate). This analysis has demonstrated that the way gender is done in the UN [1] excludes gender from the realm of war (only sexual-based violence happens in war), [2] excludes men from the field of gender (male soldiers need to be "aware" of but are not concerned). This research has also touched upon other issues, such as, the way gender is done in the UN [3] excludes women from the realm of war (their agency is restricted to being victims), and [4] excludes women from the realm of peace (achieving a 'critical mass'). Further research would need to be done to validate point [3] and [4].

Indeed, 'gender-awareness' technology contributes to marginalising women and reinforcing dominant masculinities. Further, it associates sex with war and gender with peace ('doing gender' is 'making aware' of sexual violence that 'women' suffer in 'war') - while, for example, there is also domestic violence in peace (peace being constructed as starting when conflicts end). Gender should be associated with both war and peace: 'doing gender in war' would imply looking at the formation of militarised masculinities and feminities, and the agency of women as active participants in war; 'doing gender in peace' would involve looking at gender as 'lived identity', which fluctuates from women to men and from men to women, through which all forms of gender-based violence are examined. ${ }^{225}$

Thus, this research contributes to validating arguments that the way the UN is

225 Shepherd, Gender, Violence and Security: Discourse as Practice. 
"doing gender" contributes to further de-politicising gender. ${ }^{226}$ On the one hand, the UN is doing 'sex' in war, which becomes a political tool: 'technology of genderawareness' means 'technology of sex in war'. However, one could argue that even sex is not done in peace (e.g. domestic violence is not addressed, although there is often an increase in domestic violence in peace). The way gender is done through training shows that a comprehensive discourse on gender is not included in peace and security, hence contributing to de-politicising 'gender' as a concept. It is important to acknowledge the efforts and progress made by the UN, however the discourse of 'gender-awareness' they offer does not fully engage with a critical concept of gender. Rather it is a technological 'tool' constructing "sex-awareness on women's issues", embedded in the Foucauldian knowledge-power.

226 MacKenzie, "Reconstructing Women? Post-Conflict Security and the Return to "Normal" in Sierra Leone"; Cockburn, From Where We Stand: War, Women's Activism and Feminist Analysis, Enloe, Maneuvers: The International Politics of Militarizing Women's Lives; Cohn, "Sex and Death in the Rational World of Defense Intellectuals"; Hansen, "The Little Mermaid's Silent Security Dilemma and the Absence of Gender in the Copenhagen School"; Pankhurst, ed. The 'Sex War' and Other Wars: Towards a Feminist Approach to Peace Building. 


\section{CONCLUSION}

This research thesis has sought to answer the question of how the discourse of 'gender-awareness' is constructed through UN gender-training material for peacekeepers, and how this discourse contributes to shaping representations of gender, violence and security. I have discussed the discursive formation of 'genderawareness' in the UN DPKO gender-training policy around three central points (discursive sites). From the analysis of these nodal points, I have attempted to show that 'gender-awareness' as a discourse within UN gender training is composed of: [1] gender that equates 'sex' and 'women', [2] gender training in relation to violence that reproduces the dichotomy between women as 'victims' and men as 'heroes', and [3] gender skill-sets in relation to violence and security that emphasise universals such as women's rights and ignore cultural contexts in its approach to gender.

This discourse constructs what (male) peacekeepers need to be aware of in the realm of gender, violence and security. It has allowed me to identify both objects (of knowledge, i.e. what is produced as truth) and the way that subjects (agents: male peacekeepers, and non-agents: women) are positioned in the UN discourse.

From this argument, I have discussed how the discourse of 'gender-awareness' training is further established as a (disciplinary) tool which seeks to control and regulate (male peacekeeper) subjects' behaviours and their understanding (knowledge) of the relations between gender, violence and security. The discourse of 'gender-awareness' training as a technology shows that certain notions of feminities (women as peacemakers and as victims) and masculinities (image of the militarised hero) are constructed as being the truth, which in turn contributes to shaping subjects (male soldiers) accordingly.

Thus, the discourse of 'gender-awareness training' appears to further (re)produce traditional stereotypes of feminities and masculinities in the military field (peace and security). This discourse fails to provide any critical thinking about gender and fails to truly challenge the way the UN has previously been 'doing' and 
understanding gender. The discourse of 'gender-awareness' is embedded in the relationship between power and knowledge, which contributes to further depoliticising gender and excluding women from the realm of politics. ${ }^{227}$ It shows also how gender is de-politicised while sex is being politicised. Hence while gender is excluded from the realm of peace, sex is included in the realm of war. It contributes to excluding women from both the realm of peace (security) and the realm of war (violence).

I have undertaken this research through a discourse analysis that borrows from both Foucault and Shepherd. Analysing the UN DPKO gender-training material has allowed me to uncover meanings that are related to 'gender-awareness' and its relations to gender, violence and security. Hence my research feeds the academic knowledge on gender, violence and security, and could be said to be the continuation of Shepherd's work on the UNSCR 1325 and how it is constructed as a site of discourse on gender, violence and security. ${ }^{228}$ Shepherd's work has considerably inspired and strengthened this research, so I owe her a great debt. This research has also shown the validity of the use of discourse analysis, through a Foucauldian lens, to examine the objects of policies. Foucault provides us with great tools of analysis. ${ }^{229}$ However, this research would have provided broader and better results if it had encompassed an analysis of the bodies as a site of discourse, showing how gender discourse is performed and repeated through (stylised) acts. ${ }^{230}$

Finally, this research has shown that discourse is repeated - hence Shepherd's analysis of UNSCR 1325 and my analysis of UN DPKO gender training share similar

\footnotetext{
227 Cohn, "Sex and Death in the Rational World of Defense Intellectuals"; Cockburn, From Where We Stand: War, Women's Activism and Feminist Analysis; Enloe, ed. All the Men Are in the Militias, All the Women Are Victims: The Politics of Masculinity and Femininity in Nationalist Wars; Cynthia Enloe, Bananas, Beaches and Bases: Making Feminist Sense of International Politics (Berkeley, Los Angeles: Univ of California Press, 1990); MacKenzie, "Reconstructing Women? Post-Conflict Security and the Return to "Normal" in Sierra Leone".

228 Shepherd, Gender, Violence and Security: Discourse as Practice.

229 Foucault, The Archaeology of Knowledge, Trans. Am Sheridan Smith, —, Discipline and Punish: The Birth of the Prison. 1977,__, Power. Ed. James D. Faubion, Michel Foucault, Society Must Be Defended: Lectures at the Collège De France, 1975-76 (Penguin, 2003).

230 Judith Butler, "Performative Acts and Gender Constitution: An Essay in Phenomenology and Feminist Theory," Theatre Journal 40, no. 4 (1988),___ ed. Gender Trouble, Continental Feminism Reader (USA: Rowman \& Littlefield, 2003).
} 
results.

It ultimately shows that, even though the new UN initiatives on training gender have raised much enthusiasm and some of it should be celebrated, the way the UN is doing "its business", in a rigid, hierarchical, and mechanical way, inevitably influences all its practices, even those that seek to be innovative. For the UN to (re)think gender in meaningful and creative ways, it will be necessary to deconstruct the way power structures are shared (hence deconstructing hegemonic masculinities). 


\section{BIBLIOGRAPHY}

Afshar, Haleh, ed. Introduction War and Peace: What Do Women Contribute? Edited by Haleh Afshar and Deborah Eade, Development, Women, and War: Feminist Perspectives. Oxford: Oxfam GB, 2004.

Andersen, Niels Åkerstrom. Discursive Analytical Strategies: Understanding Foucault, Koselleck, Laclau, Luhmann: Policy Press, 2003.

Bastick, Megan, Karin Grimm, and Rahel Kunz. Sexual Violence in Armed Conflict: Global Overview and Implications for the Security Sector. Geneva: Geneva Centre for the Democratic Control of Armed Forces, 2007.

Butler, Judith, ed. Gender Trouble. Edited by Ann J Cahill and Jennifer Hansen, Continental Feminism Reader. USA: Rowman \& Littlefield, 2003.

-__. "Performative Acts and Gender Constitution: An Essay in Phenomenology and Feminist Theory." Theatre Journal 40, no. 4 (1988): 519-31.

Cockburn, Cynthia. From Where We Stand: War, Women's Activism and Feminist Analysis. London, New York: Zed Books, 2007.

Cohn, Carol. "Sex and Death in the Rational World of Defense Intellectuals." Signs 12, no. 4 (1987): 687-718.

Cox, Robert W. "Gramsci, Hegemony and International Relations: An Essay in Method." Millennium: Journal of International Studies 12, no. 2 (1983): 162-75.

Danaher, Geoff, Tony Schirato, and Jen Webb. Understanding Foucault. Australia: Allen \& Unwin, 2000.

DeGroot, Gerard J. "A Few Good Women: Gender Stereotypes, the Military and Peacekeeping." International Peacekeeping 8, no. 2 (2001): 23-38.

Dow, Joanne. "Mainstreaming Gender or Mainstreaming Women? - a Feminist Critique of UNSCR 1325." Thesis submitted in partial fulfilment of the requirements for the Master of International Relations - Victoria University of Wellington, 2008.

Enloe, Cynthia, ed. All the Men Are in the Militias, All the Women Are Victims: The Politics of Masculinity and Femininity in Nationalist Wars. Edited by Lois Ann Lorentzen and Jennifer Turpin, The Women and War Reader. New York, London: New York University Press, 1998.

- - Bananas, Beaches and Bases: Making Feminist Sense of International Politics. Berkeley, Los Angeles: Univ of California Press, 1990. 
Berkeley, London: Univ of California Press, 2000.

Epstein, Steven. "An Incitement to Discourse: Sociology and the History of Sexuality." Sociological Forum 18, no. 3 (2003): 485-502.

Finnemore, Martha. "Norms, Culture, and World Politics: Insights from Sociology's Institutionalism." International Organization 50, no. 2 (1996): 325-47.

Foucault, Michel. The Archaeology of Knowledge, Trans. Am Sheridan Smith. London: Tavistock Publications Limited, 1972.

-_- Discipline and Punish: The Birth of the Prison. 1977, Trans. Alan Sheridan. New York: Vintage, 1995.

———. Power. Ed. James D. Faubion. New York: New Press, 2000.

Penguin, 2003.

Goldblatt, Beth, and Sheila Meintjes, eds. South African Women Demand the Truth. Edited by Meredeth Turshen and Clothilde Twagiramariya, What Women Do in Wartime: Gender and Conflict in Africa. London; New York: Zed Books Ltd, 1998.

Hall, Stuart. Representation: Cultural Representations and Signifying Practices: Sage Publications Ltd, 1997.

Hansen, Lene. "The Little Mermaid's Silent Security Dilemma and the Absence of Gender in the Copenhagen School." Millennium: Journal of International Studies 29, no. 2 (2000): 285-306.

Hobbes, Thomas. Leviathan. Edited by C. B. Macpherson: Baltimore, Penguin Books [1968], 1961 Reprint.

Hudson, Natalie Florea. "En-Gendering Un Peacekeeping Operations." International Journal 6o, (2005): 785-808.

Katzenstein, Peter J. The Culture of National Security: Norms and Identity in World Politics: Columbia Univ Press, 1996.

Krause, Ulrike. "Women in Peace and Conflict? The Need of Female Representation and Participation." A Different View no. 33 (2009): 23-25.

Lyytikäinen, Minna. "Gender Training for Peacekeepers: Preliminary Overview of United Nations Peace Support Operations." UN-INSTRAW Gender, peace and Security Working paper 4, 2007.

Mackay, Angela. "Training the Uniforms: Gender and Peacekeeping Operations." Development in Practice 13, no. 2/3 (2003): 217-22. 
MacKenzie, Megan. "Reconstructing Women? Post-Conflict Security and the Return to "Normal" in Sierra Leone." Paper presented at the Canadian Political Science Association Annual, 2007.

McHoul, Alec, and Wendy Grace. A Foucault Primer: Discourse, Power and the Subject. Malaysia: Melbourne University Press, 1993.

McKay, Susan, ed. Reconstructing Fragile Lives: Girls' Social Reintegration in Northern Uganda and Sierra Leone. Edited by Caroline Sweetman, Gender, Peacebuilding, and Reconstruction. Oxford: Oxfam focus on gender, 2005.

McLean, Iain, and Alistair McMillan. Oxford Concise Dictionary of Politics. New York: Oxford University Press, 2003.

Nandy, Ashis. The Intimate Enemy: Loss and Recovery of Self under Colonialism. Delhi: Oxford University Press, 1983.

Olsson, Louise. "Gender Mainstreaming in Practice: The United Nations Transitional Assistance Group in Namibia." International Peacekeeping 8, no. 2 (2001): 97-110.

_—_. "Mainstreaming Gender in Multidimensional Peacekeeping: A Field Perspective." International Peacekeeping 7, no. 3 (2000): 1-16.

Pankhurst, Donna. "The 'Sex War' and Other Wars: Towards a Feminist Approach to Peace Building." Development in Practice 13, no. 2-3 (2003): 154-77.

Paternek, Margaret A. "Norms and Normalization: Michel Foucault's Overextended Panoptic Machine." Human Studies 10, no. 1 (1987): 97-121.

Prugl, Elisabeth. "Gender and War: Causes, Constructions, and Critique." Perspectives on Politics 1, no. 02 (2003): 335-42.

Puechguirbal, Nadine. "Gender Training for Peacekeepers: Lessons from the DRC." International Peacekeeping 10, no. 4 (2003): 113-28.

Purkarthofer, Peter. "Gender and Gender Mainstreaming in International Peacebuilding." Paper presented at the ISA Conference, 22-25 March 2006.

Said, Edward. Orientalism. New York: Vintage, 1979.

Schulz, Sabrina, and Christina Yeung, eds. Private Military and Security Companies and Gender. Edited by Megan Bastick and Kristin Valasek., Gender and Security Sector Reform Toolkit. Geneva: DCAF, OSCE/ODIHR, UN-INSTRAW, 2008.

Shapiro, Michael J. Language and Political Understanding: The Politics of Discursive Practices. New Haven, London: Yale University Press, 1981. 
Shepherd, Laura J. Gender, Violence and Security: Discourse as Practice. London; New York: Zed Books, 2008.

Shikola, Teckla, ed. We Left Our Shoes Behind. Edited by Clothilde Twagiramariya and Meredeth Turshen, What Women Do in Wartime: Gender and Conflict in Africa. London and New York: Zed Books Ltd, 1998.

Stiehm, Judith H. "Women, Peacekeeping and Peacemaking: Gender Balance and Mainstreaming." International Peacekeeping 8, no. 2 (2001): 39-48.

Turshen, Meredeth, ed. Women's War Stories. Edited by Clothilde Twagiramariya and Meredeth Turshen, What Women Do in Wartime: Gender and Conflict in Africa. London; New York: Zed Books Ltd, 1998.

United Nations Department of Peacekeeping Operations, (UN DPKO). Gender and Peacekeeping Operations in-Mission Training. New York: UN DPKO, 2004.

_——. "Gender Mainstreaming in Peacekeeping Operations - Progress Report." UN DPKO, 2005.

-_— Gender Resource Package For Peacekeeping Operations. New York: UN DPKO, 2004.

Vayrynen, Tarja. "Gender and UN Peace Operations: The Confines of Modernity." International Peacekeeping 11, no. 1 (2004): 125-42.

Wendt, Alexander. "Anarchy Is What States Make of It: The Social Construction of Power Politics." International Organization 46, no. 2 (1992): 391-425.

Whitworth, Sandra. Men, Militarism, and Un Peacekeeping: A Gendered Analysis: Lynne Rienner Publishers, 2004.

\section{Internet sources :}

http://www.genderandpeacekeeping.org/.Accessed 15/o1/2010

http://unscr1325.org/. 10/o1/2010

(UNIFEM), United Nations Development Fund for Women.

www.womenwarpeace.org/docs/Annotated 1325.pdf. 